\title{
An empirical exploration of the link between reporting to stakeholders and corporate social responsibility reputation in the Spanish context
}

\begin{abstract}
Purpose - Based on the principles of stakeholder theory, this paper explores the relationship between (1) the information reported to stakeholders in corporate social responsibility (CSR) reports and (2) companies' CSR reputation (CSRR).

Design/methodology/approach - The paper implements two regression models to test how reporting to stakeholders influences the CSRR of 84 companies included in the Spanish "MercoEmpresas Responsables" reputation index.

Findings - The results demonstrate that greater global reporting intensity to stakeholders does not necessarily mean a better CSRR. Contrarily, the reporting-reputation link depends on the intensity of reporting to specific stakeholders, such as investors, regulators and the media. The findings are explained largely by the institutional, political and business characteristics of Spain after the Great Recession of 2007-2008.

Research implications - The evidence reported in this paper confirms stakeholder theory as an adequate framework to understand corporate reporting to stakeholders and its relationship with CSRR. The findings suggest that stakeholder salience (i.e., power, legitimacy and urgency) is a key concept for understanding the reporting-reputation link better in future research.

Practical implications - In the light of the findings, companies willing to use reporting to stakeholders as a tool to improve CSRR should (1) establish regular mechanisms for monitoring stakeholder power, legitimacy and urgency, (2) provide complete information to investors in their CSR reports and (3) minimize the amount of detail provided to regulators and the media in their CSR reports.

Originality/value - There is still little empirical evidence concerning how the information to stakeholders contained in CSR reports influences the processes by which CSRR is built or destroyed. This paper contributes to the previous literature by describing how the global intensity of reporting to stakeholders and the intensity of reporting to different stakeholder groups relate to CSRR.
\end{abstract}

Keywords Corporate social responsibility, Reporting, Reputation, Stakeholders, Spain

Article classification Research paper 


\section{Introduction}

Within Europe, Spain has been one of the countries that has suffered most from the latest Great Recession of 2007-2008 (Alonso and Bremser, 2013). Before the financial crisis, Spain experienced a long period of prosperity. However, the growth and employment creation of that time were based on such factors that did not prove to be durable (Élteló, 2011). The main motor of the prosperity was the construction and real estate industry, which created jobs for millions of people and stimulated high rates of immigration in the country. Private consumption also grew considerably, always facilitated by cheap loans mainly coming from the banking industry (Élteló, 2011). Nonetheless, the economic crisis began in 2007 with a liquidity crisis in the banking system resulting from the sale of complexly structured financial products and aggravated by the severe housing bubble in the country (Alonso and Bremser, 2013). The consequences of the recession is Spain have derived in a financial and political situation that has been significantly marked by high unemployment rates, stagnation, frequent financial scandals and political corruption (Palau and Davesa, 2013). Overall, this situation has made policy-makers realise the necessity of profound reforms that began with a big transformation process in the banking industry and the labour market (Éltetó, 2011). Additionally, a series of measures have been implemented in order to increase business transparency to improve investors' and stakeholders' confidence in the business network (Carballo, 2011). Some of these measures include the creation of stress tests in the banking industry or the tightening of managers' professionalism requirements (Carballo, 2011).

Nevertheless, when the traditional foundations of business ethics fail, reforms should not only come from the government. On the contrary, new strategies are also required from companies to demonstrate their ethical standards (Milne and Patten, 2002). For example, in the search for new paths to achieve this goal, since the beginning of the twenty-first century, scholars have focused their attention on the study of reporting to stakeholders. Reporting to stakeholders refers to the disclosure of company activities demonstrating the inclusion of financial, social and environmental concerns in business operations and in interactions with stakeholders, mostly represented in the implementation of corporate social responsibility (CSR) activities. Scholars have argued that the disclosure of information to stakeholders is part of the dialogue between an ethical company and its stakeholders (Gray et al., 1995) that shows the company's strategic posture (Moneva et al., 2007) and its good CSR performance (Roberts, 1992). Based on this idea, nowadays, many companies publish CSR reports or disclose information to stakeholders online. For example, more than $80 \%$ of the companies of the Fortune 500 address CSR and stakeholder issues on their websites (Lii and Lee, 2012).

The previous literature has considered that stakeholder theory (Freeman, 1984; Ullmann, 1985) provides a useful framework to evaluate CSR through reporting activities (van der Laan et al., 2005; Prado et al., 2009). Stakeholder theory is concerned with the relationships of a company with a variety of stakeholders in society. It expands the traditional economic model, which focuses exclusively on wealth maximization for shareholders (Friedman, 1970). From a stakeholder perspective, a company should attempt to meet multiple goals of a wide range of stakeholders and as such it should also report back to stakeholders on those activities. Along this line, stakeholder theory highlights that corporate accountability should move beyond simple economic or financial performance (An et al., 2011), as "the long-term 
survival and success of the corporation requires the support of all its stakeholders (and) gaining this support and approval requires a dialogue between the management of a corporation and its stakeholders" (van der Laan et al., 2005, p. 127). Thus, the stakeholder theory views reporting as a strategic tool that must consider key stakeholders to be successful (Fernández-Feijoo et al., 2014).

The stakeholder approach provides one of the most complete theoretical perspectives in the accounting literature, explaining (1) corporate motivations for reporting information to stakeholders (Roberts, 1992; van der Laan et al., 2005; Suttipun and Stanton, 2012) and (2) the relationships among reporting to stakeholders, CSR performance and financial performance (Ullmann, 1985; Moneva et al., 2007). However, this theory has scarcely been applied to the study of the effects of reporting to stakeholders on other significant and more intangible outcomes, such as corporate reputation (Pérez, 2015). For example, Hasseldine et al. (2005) identify many studies investigating the links between reporting to stakeholders and financial performance. However, these studies discover that the relationship between these two variables is frequently not significant (Ullman, 1985; McWilliams and Siegel, 2001) or, in the contexts where it is significantly positive, it is always mediated by the effects of corporate reputation (Orlitzky et al., 2003). Another line of research has linked reputation and financial performance and has found a stronger association (Toms, 2000; Roberts and Dowling, 2002). Thus, there is a commonality of the reporting-reputation link in both these lines of prior research, but a relative lack of evidence on the direct relationship between the two. Based on these ideas, we propose to fill this gap in the literature by theoretically proposing and empirically testing the relationship between reporting to stakeholders and CSR reputation (CSRR). For this purpose, the theoretical arguments defended in the paper are based on the ideas proposed by stakeholder theory.

For the purposes of this research, it is also important to define the concept "intensity of reporting to stakeholders", which is the key antecedent of CSRR suggested in the study. When exploring CSR reporting to stakeholders, previous literature has frequently referred to concepts such as "extent of disclosure" (Michelon, 2011) "volume" (Castello and Lima, 2009) or "quantity" of information (Castelo and Lima, 2006). These concepts refer to the number of words, sentences, paragraphs or pages that companies use to present their CSR activities and results in CSR reports. However, "it follows from the earlier theoretical discussion that volume of disclosure alone is not in itself a sufficient condition for the creation of reputation" (Toms, 2002, p. 264). Although in most studies reporting to stakeholders is measured by volume-based content analysis, there has been recognition that reliance on mere number of disclosures may be misleading (Michelon, 2011). On the contrary, scholars such as Hasseldine et al. (2005) or Castelo and Lima (2006) suggest that the qualitative nature of the CSR reporting to stakeholders, as oppose to mere volume, is more likely to enhance the CSRR of the company because it is closely linked to transparency and as so it increases the confidence on the company's commitment to CSR (Fernández-Feijoo et al., 2014). Based on these ideas, in the present paper we coin the concept "intensity of reporting" to include considerations of quality further than the mere quantity of information to stakeholders reported by companies in their CSR reports. Specifically, the intensity of reporting to stakeholders refers to the completeness of the information provided to stakeholders in CSR reports. As it will be further explained in the method section, the intensity of reporting to stakeholders measures how many CSR issues are 
discussed in the reports and for how many of those CSR issues the companies provide significant information about the initiatives implemented or the results achieved in each specific domain. When compared with a previous set of CSR issues defined for the research, the intensity of reporting to stakeholders refers to the percentage of issues that are discussed out of the total amount of issues that could have been discussed to achieve the maximum rating.

Based on this concept of intensity, the contributions of the paper to previous literature are twofold: (1) determining how the global intensity of reporting to stakeholders contributes to generating CSRR and (2) exploring whether the intensity of reporting to diverse stakeholders has different impacts on CSRR. We first evaluate the global intensity of reporting to stakeholders and explore its influence on CSRR. Thus, in first place we explore whether disclosing complete information is relevant to attaining CSRR or not. For the second contribution of the paper, we deconstruct reporting into dimensions containing information aimed at eight stakeholder groups (i.e., employees, customers, investors, partners, community, regulators, activists and the media). In doing this, we follow the ideas suggested by previous scholars such as Bird et al. (2007) and Melo and Garrido (2012). These scholars view CSR as a multidimensional construct and they deconstruct it according to the stakeholder theory because they consider it "inadequate and misleading to gather in one single measure attributes that are fundamentally independent" (Melo and Garrido 2012, p.12). Thus, evaluating the intensity of information reported to diverse stakeholders as independent variables will provide a clearer picture of how the information disclosed in CSR reports determines CSRR.

For these purposes we implement a content analysis of the CSR reports of 84 companies, national and foreign, operating in Spain and included in the "MercoEmpresas Responsables" index. After the content analysis, we set the reporting of information to stakeholders in relation to the CSRR of the companies as reported by this reputation index. The "MercoEmpresas Responsables" index is the Spanish Corporate Reputation Monitor (www.merco.info/es) that ranks the 100 most reputable companies in Spain. This tool is already a reference for large companies in the assessment and management of their reputation, as it is the only Spanish monitor to evaluate annually (since 2001) the reputation of the companies that operate in Spain in a systematic and rigorous way (Luna and Fernández, 2010). Thus, the purpose of this monitor is the same as the purpose of those published by Fortune and The Financial Times (Fernández and Luna, 2007).

The remainder of the paper is structured as follows. In the following section, we revise the foundations of stakeholder theory that support the positive impact of reporting to stakeholders on CSRR. Based on the arguments provided by this theory, in the third section of the paper we discuss two research hypotheses. In the method section, we describe the research sample, content analysis procedure and two regression models that we test to explore the research hypotheses. Afterwards, the findings are presented and discussed. In the final section of the paper, we present the most important conclusions of the study, along with its practical implications and the lines of research that we propose to explore in the near future. 


\section{Applications of stakeholder theory to reporting to stakeholders}

In the light of stakeholder theory (Freeman, 1984), a company is regarded as a nexus of contracts between the company and its various stakeholders and its success is dependent upon good management of all the relationships that the company has with these groups (Moneva et al., 2007). A stakeholder is "a person or group that can affect or is affected by the achievement of the organization's objectives" (Freeman, 1984, p. 46). Shareholders are, of course, a substantial class among stakeholders, but other audiences, such as customers, suppliers, employees, local communities, regulators, the media or the general public, may also be important from the perspective of stakeholder theory (Roberts, 1992).

Stakeholder theory is broadly classified into two branches: the ethical (moral, normative or prescriptive) and the managerial (positive) perspectives (Deegan and Unerman, 2011; Dong et al., 2014). The ethical branch of stakeholder theory provides prescriptions as to how companies should treat all their stakeholders equally right (Deegan, 2002). This perspective consider that all stakeholders have the right to be treated fairly by a company, and that issues of stakeholder power are not directly relevant (Deegan and Unerman, 2011). That is, "the impact of the organization on the life experiences of a stakeholder should be what determines the organization's responsibilities to that stakeholder, rather than the extent of that stakeholder's (economic) power over the organization" (Deegan and Unerman, 2011, p. 349). However, the ethical branch is found to have little descriptive and explanatory power in predicting management behaviour in relation to reporting CSR information to stakeholders (Deegan, 2002; Dong et al., 2014). On the contrary, the management branch that informs much of the previous CSR reporting studies, including this study, explicitly specifies how a company interacts with particular stakeholders based on their importance (or power) so that it can comply with their expectations and achieve legitimacy to operate (Dong et al., 2014). More specifically, the more important the stakeholder to the company, the more effort will be exerted in managing the relationship. This managerial branch defends that the expectations of the various stakeholder groups will impact on the operating and reporting policies of the company (Deegan and Unerman, 2011) in such a way that the company will not respond to all stakeholders equally, but rather will respond to those stakeholders that are deemed to be more powerful (Nasi et al., 1997).

Consistent with this managerial explanation of stakeholder theory, corporate CSR reporting is a way of demonstrating conformance to the expectations of important stakeholder groups (Elijido-Ten et al., 2010; Dong et al., 2014). This idea relates to the term "accountability", which refers to "the responsibility of an organization to disclose information regarding its performance, financial position, financing and investing, and compliance in order to assist users to make appropriate decisions" (An et al., 2011, p. 574). Thus, according to the managerial perspective of stakeholder theory, the reporting of financial, social and environmental information is part of the dialogue between a company and its stakeholders and "it provides information on a company's activities that legitimise its behaviour, educate and inform, and change perceptions and expectations" (Michelon and Parbonetti, 2012, p. 478). Along this line, scholars have underlined that one key element of any piece of CSR research should be how CSR is reported and perceived by stakeholders (Du et al., 2010). Without communication, regardless of the kind of CSR activities that are 
implemented by companies or how they are managed, the impact of CSR on stakeholder perceptions will be null or even negative (Du et al., 2010).

Based on this managerial perspective, numerous studies confirm that stakeholders increasingly demand higher levels of reporting from companies and that they do in fact influence the development of corporate reporting policies (Elijido-Ten et al., 2010; Dong et al., 2014). For example, Ullmann (1985) develops a contingency framework for predicting levels of CSR performance and reporting based on the stakeholder perspective formalized by Freeman (1984). The three-dimensional model discusses the role of the company's strategic posture towards CSR activities, its past and current economic performance and stakeholder power.

A company's strategic posture towards CSR activities describes whether it responds to stakeholder demands actively or passively. A company in which the management tries to influence its corporate status with key stakeholders through CSR activities (e.g., to achieve optimal levels of interdependence) possesses an active posture. On the contrary, if a company's management is not continuously monitoring its position with stakeholders and is not developing specific programmes to address stakeholder influences, then the company is perceived to possess a passive strategic posture. Ullmann's (1985) framework suggests that the more active the strategic posture of a company, the greater its expected CSR performance and reporting to stakeholders. Somehow, developing CSR activities and reporting CSR information to stakeholders are seen as parts of an active stakeholder management strategy (Kent and Chan, 2003).

As far as the economic performance of the company is concerned, Ullmann (1985) proposes that the better the economic performance of a company, the greater its CSR performance and reporting to stakeholders. This scholar considers that a company's past and current economic performance "determines the relative weight of a social demand and the attention it receives from top decision makers" (Ullmann, 1985, p. 553). Economic demands usually have priority over social demands, especially in periods of low profitability and in situations of high debt. Additionally, economic performance also "influences the financial capability to undertake costly programs related to social demands" (Ullmann, 1985, p. 553). Therefore, it seems that a positive economic performance is a prerequisite for companies before meeting any other demands from stakeholders (Roberts, 1992).

As a third component of the model, stakeholder power reflects the theoretical basis of Ullmann's (1985) framework. It explains that a company is responsive to the intensity of stakeholder demands (Roberts, 1992). Specifically, the power of a stakeholder group is a function of the stakeholder's degree of control over the resources required by the company and how critical these resources are to the continued viability of the company (Elijido-Ten et al., 2010). "The more critical stakeholder resources are to the continued viability and success of the corporation, the greater the expectation that stakeholder demands will be addressed" (Roberts, 1992, p. 599). For example, when the company has a low level of dependence on the stakeholder, the company does not need to be responsive to stakeholder demands, leaving the stakeholder no choice but to find an ally to indirectly influence the company (Elijido-Ten et al., 2010). Conversely, when the company depends heavily on the stakeholder for survival, stakeholders can express their demands directly to 
the company and the company is obliged to respond to their requests. In this context, "if social responsibility activities are viewed as an effective management strategy for dealing with stakeholders, a positive relationship between stakeholder power and social performance and social disclosure is expected" (Roberts, 1992, p. 599).

Nonetheless, some researchers have considered stakeholder power in conjunction with other stakeholder attributes (Deegan and Unerman, 2011). For example, Mitchell et al. (1997) argue that it is not only stakeholder power that counts when understanding the stakeholder-company relationship. On the contrary, the relevance of stakeholders depends on stakeholder salience, which refers to the combination of stakeholder power, legitimacy and urgency. Stakeholder power means that a stakeholder can make the company do something that it would not otherwise have done. That is, the stakeholder can certainly exert its influence on the company (Deegan and Unerman, 2011). Legitimacy exists when the stakeholder's demands conform to the norms, values and beliefs of the wider community (Mitchell et al., 1997). That is, legitimacy is closely linked to the general belief that stakeholders' claims are proper, desirable or appropriate (Thorne et al., 2003). Urgency in the manager-stakeholder relationship occurs when stakeholders want their wishes to be fulfilled quickly because their demands are time sensible and important (Thorne et al., 2003). According to Mitchell et al. (1997), the most salient stakeholder group is not only powerful. Instead, the "definitive stakeholder" is "where all three of the stakeholder attributes -power, legitimacy and urgency- are perceived by managers to be present" (Mitchell et al., 1997, p. 878). A stakeholder exhibiting both power and legitimacy, and with an urgent claim, means managers have a clear and immediate mandate to give priority and attend to that stakeholder's claim (Dong et al., 2014). In contrast, moderately salient stakeholders possess only two of the attributes described by Mitchell et al. (1997). They are "expectant stakeholders", but either lack power to enforce change or lack urgency or legitimacy to demand change (Dong et al., 2014). A third group of stakeholders is termed "latent stakeholders", who are a low salience class of stakeholders only possessing one attribute and having the least power to seek change in company's activities (Dong et al., 2014). Thus, in their various combinations the attributes suggested by Mitchell et al. (1997) are indicators of the amount of management attention awarded to a given stakeholder (Sweeney and Coughlan, 2008). The more salient the stakeholder to the company, the more effort will be exerted in managing the relationship. This being so, information is viewed as a "major element that can be employed by the organisation to manage (or manipulate) the stakeholder in order to gain their support and approval, or to distract their opposition and disapproval" (Islam and Deegan, 2008, p. 10). Thus, companies will accommodate the intensity of reporting to different stakeholder groups by giving greater attention to especially salient stakeholders in the context of their businesses.

Ullmann's (1985) theoretical framework has subsequently been tested empirically to explore the correlations among the three dimensions of the model and corporate reporting to stakeholders (Roberts, 1992; Kent and Chan, 2003). The findings of these studies mostly confirm that diverse measures of stakeholder power, strategic posture and economic performance are significantly related to levels of reporting to stakeholders. Similarly, Mitchell's et al. (1997) theoretical framework has also been empirically tested with positive results. For example, Dong et al. (2014) base their study on the salience of stakeholder groups to investigate their influence on corporate reporting. Their findings suggest that 
according to the corporate annual and CSR reports produced by companies listed in the Shanghai and Shenzhen Stock Exchanges, there are emerging salient stakeholders in China, such as the central government or international consumers.

Based on Ullmann's (1985) and Mitchell's et al. (1997) frameworks, in the following section of the paper we discuss the idea that companies that behave proactively towards their stakeholders use reporting as one of their strategies to manage the company-stakeholder relation and the generation of CSRR. Additionally, we suggest that the intensity of reporting to different stakeholders is directly related to stakeholder salience, which also conditions the impact of reporting to stakeholders on CSRR. Even though stakeholder theory has scarcely been applied to the empirical testing of the connection between reporting to stakeholders and CSRR so far, we consider that similar arguments that relate reporting to financial and CSR performance can also be applied to the exploration of CSRR. For example, Roberts (1992) suggests that the stakeholder theory could also be adapted to investigate other related issues, such as the effects of different types of reporting to stakeholders on financial and CSR performance or even other dependent variables, such as alternative measures of CSR performance or corporate reputation.

\section{Research hypotheses}

The first goal of this paper is to test the relationship between the global intensity of reporting to stakeholders and the CSRR. For this purpose, we consider that arguments related to the strategic posture of a company towards CSR activities (Ullmann, 1985) support a positive relationship between the global intensity of reporting to stakeholders and the CSRR.

Specifically, nowadays "due to public pressures, companies feel increasingly more accountable as they become more embedded within society, compelling them to become more transparent and report (more) on activities that may significantly impact their stakeholders" (Morf et al., 2013, p. 88). Thus, a strategic plan for managing stakeholder relationships involves showing an active posture towards CSR activities (Roberts, 1992; Chan et al., 2014). Based on these ideas, Ullmann (1985) expects that the active posture of the company towards CSR activities will derive a greater intensity of reporting to stakeholders to improve their perceptions and benefit the corporate-stakeholder relationships (Ullmann, 1985; Roberts, 1992; Kent and Chan, 2003). These arguments are explained by FernándezFeijoo et al. (2014) in terms of transparency. Specifically, these scholars defend that reporting to stakeholders is a communication tool companies use to convey a transparent image. Companies are continuously highlighting the need of transparent reporting to stakeholders and, as part of the CSR communication strategy, each company must determine its required level of transparency that depends on the pressure of specific stakeholders in the industry (Fernández-Feijoo et al., 2014).

Along this line, Ullmann (1985) considers that showing an active strategic posture towards CSR activities reduces the information asymmetry between the company and its stakeholders and as a consequence improves the relationships between them. This scholar asks the questions of whether the market reacts to CSR information and whether reporting to stakeholders contains additional information facilitating stakeholder decisions. He 
suggests that companies reporting information to stakeholders on a voluntary basis are convinced that the value of this information is not zero and that it improves their relationships with stakeholders. Specifically, the stakeholders' evaluation of the reported information will benefit the company and the benefits outweigh the costs of collecting, compiling and disseminating the information. Those companies that are more committed to their stakeholders show better strategic consistency and a more active posture towards CSR activities than shareholder-oriented companies and, in the end, this active orientation derives better results for the company (Moneva et al., 2007). Along this line, in a study of strategic performance, Chakravarthy (1986) defends the adequacy of stakeholder satisfaction measures (e.g., reputation) as indicators of strategic performance. He argues that well-adapted companies (i.e., companies with a strategic performance that is considered active and excellent) realize that co-operation with multiple stakeholders is a necessary condition for excellence, as suggested by the reputation surveys and indicators developed by international organizations such as Fortune or The Financial Times.

In summary, the more active the strategic posture of a company, the greater its expected reporting to stakeholders, at the same time that demonstrating that it acts in a proactive, responsible manner can provide a company with major benefits, including improved CSRR and relations with stakeholders. Thus, we expect that the more complete the global information the company reports to its stakeholders (i.e., the higher the intensity of reporting to stakeholders), the greater the CSRR that it achieves. Based on these ideas, we propose the first research hypothesis of the paper:

\section{H1: The intensity of global reporting to stakeholders has a positive impact on CSRR.}

Furthermore, the managerial perspective of stakeholder theory defends that stakeholder groups are identified by the company by reference to the extent to which it believes the interplay with each group needs to be managed in order to further the interests of the company (Deegan and Unerman, 2011). This argument implies that the more important (or salient) the stakeholder to the company, the more effort will be exerted in managing its demands, including different intensities of CSR reporting to different stakeholder groups (Kent and Chan, 2003; van der Laan et al., 2005). Following these ideas, the arguments related to the salience (power, legitimacy and urgency) of stakeholders in their relationship with a company make us believe that not all the stakeholders are offered the same intensity of CSR information (Neu et al., 1998; Dong et al., 2014) and that different intensities of CSR reporting to stakeholder groups may consequently have different effects on CSRR. Hence, stakeholder theory also provides us with a potentially useful theoretical framework for examining the relationship between the intensity of reporting to different stakeholders and the CSRR.

According to Mitchell et al. (1997), the stakeholders who will be given priority by companies are those that are perceived to be powerful, legitimate and possess urgent claims. These three attributes allow the authors to differentiate among definitive, expectant and latent stakeholders (Dong et al., 2014). For example, companies will react to the demands of employees (as a definitive stakeholder group) when unemployment is a critical concern for society, or they will react to the expectations of multinational buying companies when such 
companies are the major customers of the industry and as so they also fall into the definitive cohort (Dong et al., 2014). This classification suggested by Mitchell et al. (1997) is also in accordance with the definition of audiences as primary or secondary stakeholders (Clarkson, 1995). Primary stakeholders are highly salient groups without whose continuing participation the company cannot survive as a going concern. On the contrary, secondary stakeholders are those who are not engaged in transactions with the company and are not essential for its survival (Clarkson, 1995).

This process of prioritizing stakeholders reflects the degree to which a company perceives itself to be accountable to diverse stakeholder groups (Morf et al., 2013). Therefore, stakeholder salience determines not only the importance that the company gives to each stakeholder group but also the intensity of reporting to each stakeholder (Ullmann, 1985). Morf et al. (2013) consider that companies will act in such a way as to satisfy the demands of the focal stakeholders, becoming especially transparent through the communication of their CSR activities in favour of these stakeholder groups. Joining this reasoning to the ideas raised in the first research hypothesis, then the most salient stakeholders will receive more complete information than less salient groups and as such the intensity of reporting that they receive will also have a greater impact on CSRR. According to Islam and Deegan (2008) and Dong et al. (2014), from the perspective of the stakeholder theory, a company's reporting of CSR information to their stakeholders is a way of responding to salient groups in order to receive their necessary support for survival of the company. Thus, reporting to stakeholders is implemented in order to demonstrate conformance to stakeholder expectations (Dong et al., 2014).

But which are the most salient stakeholders for companies? To whom are companies providing more and better information in their CSR reports? Morf et al. (2013) explain how "over the course of history, corporations have focused on different stakeholder groups as the targets of their social reporting" (p. 102). Their study indicates that corporate accountability first extended to discussing employee benefits, but, as national and global events have transpired, companies have become more accountable to other stakeholders, such as the community and consumers, focusing their reporting of information to stakeholders on CSR activities such as protecting the environment and supporting educational and social programmes, as well as ensuring that their entire supply chain meets the reporting guidelines. However, the previous literature has been unable to conclude which stakeholder group, of the multiple stakeholders that companies are accountable to nowadays, exerts the greatest influence over companies' decision making in respect of information reported to stakeholders in CSR reports. For example, Wilmshurst and Frost (2000) find that companies' reporting to stakeholders is especially influenced by customers, financial institutions, communities and suppliers. In another study, Neu et al. (1998) conclude that companies are more responsive to the demands of financial stakeholders and government regulations than to the concerns of environmentalists and other stakeholder groups. Similarly, Llena et al. (2007) explain the increase of environmental information in the annual reports of Spanish listed companies because of new government regulations (i.e., the new Spanish compulsory accounting standard of 25 March 2002). Dong et al. (2014) highlight the salience of international consumers over industry associations, local communities and employees. 
These difficulties in clearly determining the most salient stakeholders may be explained by the role of context (Dong et al., 2014). Specifically, scholars have considered that the role of stakeholder pressures on CSR reporting may be specific to context, because each country and industry has its unique social, political, regulatory, economic and cultural orientation that may lead to significant differences in stakeholder salience in relation to approaches to CSR (Dong et al., 2014). In this regard, Smith et al. (2005) highlight that the salience of stakeholders is moderated by institutional factors in particular countries and industries where the role of a company and its stakeholders may be different to other countries and industries. Thus, both the practice and study of reporting to stakeholders should be put within a country's and industry's specific institutional environment in order to capture the influence of their particular context over corporate behaviour (Elijido-Ten et al., 2010). Along this line, the political and economic context of Spain after the 2007-2008 recession has highlighted several social concerns such as the high unemployment rates in the country, liquidity problems among companies, severe corruption or frequent financial and business scandals (Éltetó, 2011; Palau and Davesa, 2013). These concerns could suggest that the demands of employees, investors and/or regulators may be currently more salient than other stakeholders' expectations for companies operating in Spain. However, as far as we know, no research has tested this intuition yet.

Based on these ideas, we expect different intensities in the effects of reporting to diverse stakeholders on CSRR. However, there is not enough empirical evidence to suggest which stakeholder groups are more powerful in the context of our research. Thus, we have to propose a broad hypothesis that suggests the following:

\section{H2: The intensity of reporting to each stakeholder group is different. Thus, the reporting of information to each stakeholder group has a different impact on CSRR.}

\section{Method}

Data

To explore the research hypotheses, we use the 100 most reputable companies in Spain, national and foreign, according to the 2013 "MercoEmpresas Responsables" index. Out of the 100 companies, 16 could not be included in the analysis because they do not regularly publish CSR reports and thus the intensity of their reporting to stakeholders could not be evaluated.

The "MercoEmpresas Responsables" index is elaborated annually by the Spanish Corporate Reputation Monitor (Monitor Empresarial de Reputación Corporativa, MERCO). MERCO is articulated as a research project led by the Complutense University of Madrid and Análisis e Investigación ( $A E L)$, the main Spanish market research company. As a sign of the rigour of the project, the methodology developed by MERCO is the only one in Spain that has been independently audited by KPMG in accordance with the ISAE 3000 standard. As part of the project, the "MercoEmpresas Responsables" index is a ranking of the top 100 companies with the highest CSRR in Spain. This indicator evaluates the opinions of different stakeholders, who select and evaluate companies through a postal survey. The survey 
evaluates companies on three items related to CSR and corporate ethics. These items are: (1) ethical corporate behaviour; (2) community commitment; and (3) social and environmental responsibility.

The ranking is built in two stages. First, the survey is administered to major Spanish managers. In 2013, the survey was mailed to the top managers of the 2,850 companies in Spain with revenues exceeding $€ 50$ million. The final 2013 sample comprised 1,503 questionnaire responses. This stage provisionally proposes the 100 most reputable companies in Spain that are eligible among the companies for which revenues are publicly available and the stocks are traded on the Madrid Stock Exchange General Index (Cegarra et al., 2009). The Madrid Stock Exchange General Index is an official index of the Spanish Stock Exchange's Continuous Market (Fernández et al., 2012). Second, each of these companies is evaluated by several raters: financial analysts, non-governmental organizations (NGOs), unions, consumer associations and opinion leaders. These ratings are verified through research into the companies' own reports and through a "merit questionnaire" created by MERCO analysts. Finally, the definitive ranking is drawn up and released. The results of the "MercoEmpresas Responsables" index are published each year by Cinco Días, one of the most renowned business journals in Spain (Delgado et al., 2013), and they are also publicly available on the MERCO website.

\section{Content analysis procedure}

Contrary to CSRR, no independent organization has yet developed a procedure to analyse and measure the reporting to stakeholders of companies operating in Spain. Thus, there is no available ranking of companies based on the intensity of their reporting to stakeholders in Spain. For this reason, we had to create our own new procedure to measure the reporting to stakeholders implemented by the companies in the study. Specifically, a content analysis of 2011 CSR reports was undertaken (Gamerschlag et al., 2011; de los Ríos et al., 2012). In this regard, "there is a large and complete literature on corporate social, ethical and environmental reporting that uses content analysis as a method to gather data on disclosure in annual reports" (Guthrie and Abeysekera, 2006, p. 4) and its usefulness for the accounting literature has been extensively proved (Milne and Adler, 1999).

To perform the content analysis, we followed the procedure suggested by Krippendorf (1980), which helped us to achieve the necessary reliability in terms of stability, reproducibility and accuracy (Milne and Adler, 1999). We contacted and trained two independent judges to explore the information disclosed in the CSR reports of the companies in the sample. The independent judges were research fellows hired ad hoc for the study. We chose experienced coders for the task because previous research has demonstrated that the reliability of content analysis of CSR reports may be compromised if the procedure is implemented by inexperienced judges (Milne and Adler, 1999). Anyway, according to Bakeman and Gottman (1986) and Bravo et al. (2012), a training and supervision system should be established for the judges. For this purpose, and after we had explained the purposes of the research to the judges, both we and the judges independently performed an initial examination of some of the CSR reports gathered for the research. Afterwards, a meeting was scheduled to discuss the most relevant incidents and obtain consensus on the analytic criteria. Subsequently, regular meetings to discuss new incidents 
and refine the criteria were arranged. Specifically, each CSR report was analysed by the two judges independently and the interjudge agreement coefficients in the categories analysed were calculated according to the procedure proposed by Perrault and Leigh (1989). The purpose of this estimation was to obtain a sufficient coefficient of concordance to ensure that the empirical study was rigorous and reproducible (Milne and Adler, 1999). The coefficients of concordance in the categories analysed were in all cases higher than $90 \%$, which is acceptable for this type of method (Neüendorf, 2002) and similar to those in the previous literature (Gram, 2007; Bravo et al., 2012).

Fombrun et al.'s (2000) definition of stakeholders was used to classify the information reported to stakeholders by the companies in the "MercoEmpresas Responsables" index. The selected stakeholders were: (1) employees; (2) customers; (3) investors; (4) community; (5) regulators; (6) partners; (7) activists; and (8) media. This selection of stakeholders included primary and secondary stakeholders as well as stakeholders with voting, economic and political power (Freeman, 1984; Kent and Chan, 2003). The items in each stakeholder group were taken from previous papers that measured CSR activities in different industries. The employee dimension included twelve items that evaluated information mostly referring to working conditions and fair treatment of employees (Brammer and Pavelin, 2004; Maignan and Ferrell, 2004; Bird et al., 2007; Melo and Garrido, 2012). The customer dimension contained eleven items related to the company's commercial offering and marketing practices (Maignan and Ferrell, 2004; Bird et al., 2007; Misha and Suar, 2010; Michelon, 2011; Soppe et al., 2011; de los Ríos et al., 2012; Melo and Garrido, 2012). The investor dimension consisted of six items concerning the ethical relationship of the company with its investors and shareholders (Misha and Suar, 2010). The information orientated towards the community contained eight items related to social, environmental and economic concerns (Brammer and Pavelin, 2004; Maignan and Ferrell, 2004; Bird et al., 2007; Misha and Suar, 2010; Michelon, 2011; Melo and Garrido, 2012). The regulator dimension included four items referring to the compliance with laws and regulations (Misha and Suar, 2010; Soppe et al., 2011). The partner dimension included eight items that evaluated how the company promoted CSR along the supply chain (Misha and Suar, 2010). The activist dimension consisted of two items related to the partnership of the company with other organizations devoted to CSR causes (Maignan and Ferrell, 2004; Misha and Suar, 2010). Finally, the media dimension included two items that covered the management of relationships with the media. Additional information regarding reporting to stakeholders and the items that comprised each stakeholder group is shown in Table 1.

\section{Insert Table 1 about here}

During the content analysis, each CSR report was evaluated similarly to the Kinder, Lydenberg and Domini (KLD) database, which comprises numerical assessments of several CSR dimensions (Hart and Sharfman, 2012). We chose the KLD rating system because scholars have confirmed its construct and concurrent validity, so its adequacy for evaluating CSR has been proved (Sharfman, 1996; Hart and Sharfman, 2012). Thus, each company was given a value of either 0 or 1 for each item depending on whether it communicated on this aspect (1) or not (0), that is, the response to "This company informs about significant activities implemented (or results achieved) in this domain". The final score of a company for a stakeholder group was the weighted average of the evaluations that it obtained for 
each of the items forming the dimension. Based on the procedure proposed by Krippendorf (1980), we also calculated the global reporting score of each company. This variable represented the sum of the scores that each company obtained for all its stakeholder groups. For example, let us say that a company obtained the following scores for each of the dimensions of reporting to stakeholders: employee $=0.58$, customer $=0.27$, investor $=1.00$, partner $=0.37$, community $=0.50$, regulator $=0.25$, activist $=1.00$ and media $=0.00$. The company's global reporting score would be the sum of these scores, that is, 3.97.

\section{Research models}

We use two models to explore the research hypotheses in the paper. The two models are as follows:

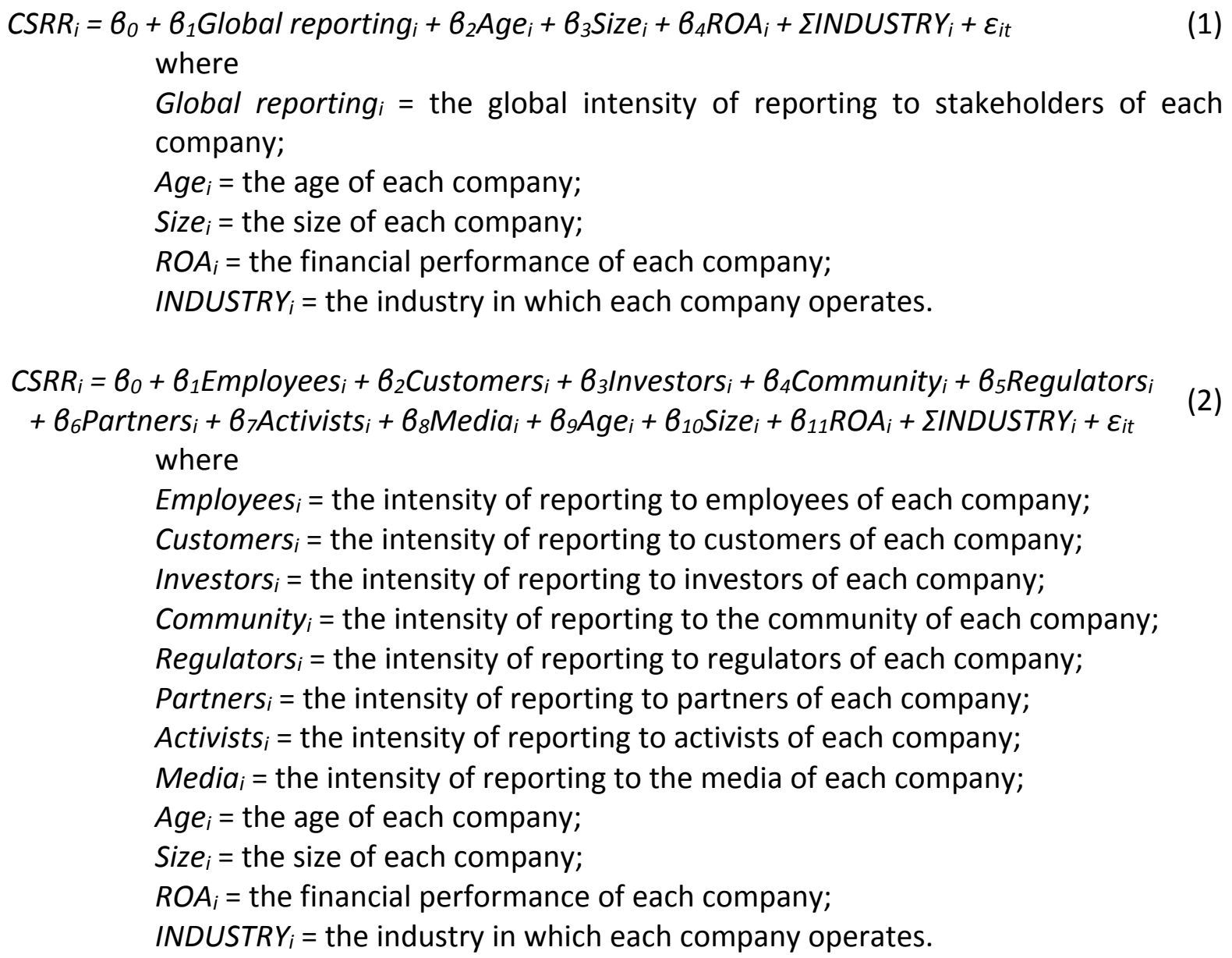

The first model (1) includes the global reporting measure (i.e., the global intensity of reporting to stakeholders of each company) as the independent factor that helps to explain the CSRR scores. Thus, model (1) explores the first research hypothesis (H1). The second model (2) splits the global reporting measure into the eight stakeholder groups, each one referring to the intensity of reporting to employees, customers, investors, community, regulators, partners, activists and the media. The eight stakeholder groups are the independent variables in this model. Thus, regression (2) explores the second research hypothesis $(\mathrm{H} 2)$ of this paper. 
In each of the two models, control variables are also included in the analyses to avoid bias in the results. These control variables are divided into two groups. The first group includes variables referring to the company's situation. First, we control for company age. This variable is measured as the number of years of existence of the company from its foundation date. Corporate size is also controlled. For this purpose, we measure it as the log of the number of employees (Waddock and Graves, 1997; Surroca et al., 2010). A large number of employees inflates audiences' familiarity with corporate activities, because employees act as brand ambassadors who transmit information about the company quickly to people in their close surroundings. Thus, more employees means more people talking about the company and building its CSRR. A large number of employees also makes the interactions of companies with their stakeholders more numerous and significant. Thus, for stakeholders, size and CSRR may be easier to infer from the number of employees than from the total assets, which are difficult for external audiences to calculate. The third control variable is financial performance, measured by the ratio of pre-tax profits to total assets (ROA) (Hillman and Keim, 2001; Melo and Garrido, 2012). Strong financial performance generally signals an effective corporate strategy and resource allocation, thus helping a company to establish a good CSRR, particularly among groups of financial stakeholders, such as creditors, investors and external analysts (Fombrun and Shanley, 1990).

The second group of control variables is comprised of different dummy variables to control for industry effects. We separated this group of control variables from age, size and financial performance because the industry dummy variables do not refer to each company's specific situation. On the contrary, industry dummy variables are common to all the companies operating in the same industry. Thus, they allow us to control the effect that the industry has on the CSRR. For this purpose, companies are classified according to the standard fourdigit code provided by the Spanish National Classification of Economic Activities (Clasificación Nacional de Actividades Económicas, CNAE, Royal Decree 475/2007 of 13 April). Previous studies have noted that there are significant industry effects in CSR and reputation data (Waddock and Graves, 1997). Using the CNAE industry classification, we allocate each company to one of ten industries: manufacturing, utilities, construction, retail, transportation and tourism, telecommunications, holding activities, finance, business services, and social and public services.

\section{Findings}

Table 2 presents the correlation matrix and basic descriptive statistics for all the dependent and independent variables incorporated into the study. The low correlations give us no reason to suspect multicollinearity (Fombrun and Shanley, 1990). In general, although some of the variables have correlations with each other that are statistically significant, most of these correlations are lower than 0.50 (only one correlation is 0.53 ). This result confirms that reporting to stakeholders is multidimensional and provides additional support for the separate analysis of the eight stakeholder groups theoretically proposed in this paper.

We also implement a means comparison test among the intensities of reporting to the eight stakeholder groups (see the second column of the Table 2) to understand if there are significant differences among them. The findings show that there are statistically significant differences among most of the stakeholder groups in the analysis. For example, the highest 
reporting intensity is orientated to activists (mean $=0.74$ ) and its mean is significantly higher than the mean of the reporting to employees (mean=0.64), community (mean=0.60), customers (mean $=0.42$ ), regulators (mean $=0.32$ ), media (mean=0.31), partners (mean=0.27) and investors (mean=0.17). On the contrary, the difference in the intensity of reporting to employees and the community is not statistically significant as it also occurs for the intensity of reporting to regulators, media and partners (there are not significant differences among the three stakeholder groups). According to these findings, the following ranking of the intensities of reporting to stakeholders is obtained (high to low intensity of reporting): (1) activists; (2) employees and community; (3) customers; (4) regulators, media and partners; and (5) investors.

\section{Insert Table 2 about here}

To test the influence of reporting to stakeholders on CSRR, we estimate several specifications of the two models proposed in the paper. In doing so, our purpose is to test the robustness of the results of the complete models by including different control variables. Following a forward selection strategy, we first include the variables related to the research hypotheses (models $1 \mathrm{a}$ and $2 \mathrm{a}$ ) and then include the company's control variables (models $1 \mathrm{~b}$ and $2 \mathrm{~b}$ ) and the industry dummy variables (models $1 \mathrm{c}$ and $2 \mathrm{c}$ ). Thus, three different specifications are tested for each model.

The first set of specifications includes models $1 \mathrm{a}, 1 \mathrm{~b}$ and $1 \mathrm{c}$. This set reports the results of three specifications of model (1), in which the influence of the global reporting score on CSRR is evaluated. The results of these models provide an answer to the first research hypothesis (H1). Model 1a only encompasses the global reporting score as the predictor of CSRR. Model $1 \mathrm{~b}$ includes the effects of the company's control variables (corporate age, size and financial performance) together with the global reporting score. Model $1 \mathrm{c}$ is estimated including the influence of the global reporting score, the company's control variables and ten industrial dummies. Thus, it allows CSRR to vary across industries. The results of the analyses are reported in Table 3.

\section{Insert Table 3 about here}

The results demonstrate that the impact of the global intensity of reporting to stakeholders on CSRR is significant and positive in models $1 a(p=0.01)$ and $1 b(p=0.07)$, whereas it is not significant in model $1 c(p=0.39)$, in which the results are controlled by industry. These findings only support hypothesis $\mathrm{H} 1$ partially because they show that, in building CSRR, the industry in which the company operates is more informative than the global intensity of the reporting to stakeholders. To confirm that multicollinearity does not actually bias our results, we also calculate the variance inflation factors (VIF) for the independent variables included in the three specifications. The value of the VIF indicators should be less than 10, since a value of 1 is a characteristic of an orthogonal system and a value of less than 10 would indicate a non-collinear or stable system (Chatterjee and Hadi, 2012). As observed in Table 3, in all the cases, the VIF indicators are smaller than 10 (none of our results show a VIF value greater than 3 ). These results confirm that our findings are robust to multicollinearity problems. 
Given the non-significant effect of global reporting to stakeholders on CSRR in the general model, we employ model 2 to determine the reason why the impact of reporting to stakeholders vanishes in model $1 c$. The second set of specifications includes models $2 a, 2 b$ and $2 c$, in which reporting to stakeholders is deconstructed and the effects of the intensity of reporting to each of the eight stakeholder groups on CSRR are analysed independently. The results of these models allow us to provide an answer to the second research hypothesis (H2). Model 2a only encompasses the eight stakeholder groups as predictors of CSRR. The regression function is then also run to include the company's control variables (corporate age, size and financial performance) in the analysis (model 2b). Model 2c includes the eight stakeholder groups together with the company's control variables and ten industrial dummies. The results obtained in these analyses are reported in Table 4.

\section{Insert Table 4 about here}

Through independent analysis of the intensity of reporting to each stakeholder group, it can be observed that reporting orientated towards investors significantly and positively affects $\operatorname{CSRR}\left(p_{2 a}=0.00 ; p_{2 b}=0.00 ; p_{2 c}=0.00\right)$ and that reporting to regulators significantly and negatively affects CSRR $\left(p_{2 a}=0.10 ; p_{2 b}=0.05 ; p_{2 c}=0.00\right)$ in all the models proposed. Meanwhile, reporting orientated towards the media influences CSRR in the last two models $\left(p_{2 b}=0.06 ; p_{2 c}=0.03\right)$, and the effect is also negative. In none of the models CSRR is significantly influenced by reporting to employees $\left(p_{2 a}=0.94 ; p_{2 b}=0.43 ; p_{2 c}=0.59\right)$, customers $\left(p_{2 a}=0.56 ; p_{2 b}=0.45 ; p_{2 c}=0.73\right)$, community $\left(p_{2 a}=0.80 ; p_{2 b}=0.18 ; p_{2 c}=0.29\right)$, partners $\left(p_{2 a}=0.27\right.$; $\left.p_{2 b}=0.20 ; p_{2 c}=0.13\right)$ or activists $\left(p_{2 a}=0.66 ; p_{2 b}=0.65 ; p_{2 c}=0.29\right)$. These findings support hypothesis $\mathrm{H} 2$ while also explaining to some extent the non-significant results obtained for the effect of global reporting to stakeholders on CSRR (H1). In this regard, it can be observed that reporting to investors and reporting to regulators and the media affect CSRR inversely: while the impact of reporting to investors on CSRR is positive, there is a negative influence of reporting to regulators and the media on CSRR. These inverse effects might even converge to nullify the global impact of reporting to stakeholders on CSRR in model 1c. As it is also observed in Table 4, in all the cases, the VIF indicators are smaller than 10, confirming that our findings do not suffer from multicollinearity problems.

In addition to these analyses, the standardized coefficients of each variable are also calculated for all the models estimated. This enables us to remove the scale effect from the estimated coefficients and facilitates an assessment of which variables have the greatest association with the dependent variable. Of all the variables included, reporting to investors has the greatest influence, followed by reporting to regulators. This shows the effect that reporting on these stakeholder groups has on CSRR, making it even more significant than the company's own characteristics.

Regarding the control variables in the study, it can be observed that the CSRR rating varies significantly across industries in model $1 c(p=0.04)$ and also according to corporate size in models $1 b(p=0.01), 1 c(p=0.02), 2 b(p=0.01)$ and $2 c(p=0.01)$. Models $1 c$ and $2 c$ are also determined by corporate financial performance $\left(p_{1 c}=0.08 ; p_{2 c}=0.01\right)$. Only corporate age seems to be insignificant when explaining how CSRR is built $\left(p_{1 b}=0.67 ; p_{1 c}=0.87 ; p_{2 b}=0.33\right.$; $\mathrm{p}_{2 \mathrm{c}}=0.68$ ). 


\section{Discussion}

Based on arguments taken from the managerial perspective of the stakeholder theory (Deegan and Unerman, 2011; Dong et al., 2014), the findings of this study provide evidence that increasing the intensity of CSR reporting to some stakeholders may be an interesting strategy to improve the CSR reputation of companies. This statement is particularly true for significantly salient stakeholders, that is, for stakeholders with demands that have the power, legitimacy and urgency to influence the behaviour of companies in the short run (Mitchell et al., 1997). In this regard, previous scholars have theoretically suggested that the corporate strategic posture towards CSR activities, the past and current economic performance of the company and the salience of stakeholders directly affect the intensity of reporting to stakeholders (Ullman, 1985; Mitchell et al., 1997). Specifically, the stronger the active posture, economic performance and stakeholder salience, the higher the intensity of reporting to stakeholders and, as a consequence, the financial and CSR performance of the company. Nevertheless, our empirical findings suggest that only some of these ideas can be extended to the understanding of CSR reputation as an outcome of reporting to stakeholders and that the context of research plays a significant role in understanding the salience of stakeholders and the findings of this study.

As far as the first research hypothesis $(\mathrm{H} 1)$ is concerned, the findings of this study empirically show that greater global intensity of reporting to stakeholders does not always result in a better CSR reputation among listed companies operating in Spain. Applying the arguments proposed by Ullmann (1985) in his stakeholder framework, we suggested that reporting complete information to stakeholders implies an active strategic posture towards CSR activities that leads to positive intangible outcomes for the company, including CSR reputation. However, our findings contradict this idea in one of the most complete specifications of our research (model $1 \mathrm{c}$ ) and show that simply reporting large amounts of information to stakeholders is not always a guarantee of success in the generation of CSR reputation. Thus, an active strategic posture towards CSR activities seems to be important but not decisive for companies to achieve a better CSR reputation.

This finding can be partially explained by the role of other corporate characteristics that are more informative than the reporting to stakeholders when building CSR reputation (i.e., corporate size, financial performance and industry) (Brammer and Pavelin, 2004; Melo and Garrido, 2012). Specifically, the findings reported for financial performance support Ullmann's (1985) intuition that the stronger the financial performance of the company, the stronger the positive intangible outcomes for the company, including CSR reputation. Even though previous scholars have encountered some problems when applying this economic argument to the empirical exploration of the reporting-performance link (Kent and Chan, 2003), our findings confirm that financial performance is a key antecedent of CSR reputation. Thus, Ullmann's (1985) ideas concerning this variable seem to be perfectly applicable to the understanding of the reporting-reputation link among listed companies in Spain.

Additionally, the findings related to the second research hypothesis $(\mathrm{H} 2)$ explored in this paper provide a deeper understanding of this phenomenon. Our findings support the idea that the intensity of reporting to investors has positive effects on CSR reputation, while 
reporting to regulators and the media has negative effects and the reporting to the rest of stakeholders (i.e., employees, customers, community, partners and activists) has no significant impact on the CSR reputation of companies. Thus, these findings suggest that there might be compensation effects in the influence of reporting to different stakeholders on the CSR reputation of listed companies. These compensation effects contribute to a better understanding of the absence of a consistent significant relationship between the global intensity of reporting to stakeholders and the CSR reputation in model 1c. Specifically, the intensity of reporting to investors, regulators and the media inversely affects the CSR reputation in models $2 a$ to $2 c$, and the intensity of the positive vs. negative effects is very similar in the three models.

Along this line, the findings of the hypothesis $\mathrm{H} 2$ also show that the most complete CSR information is being reported to activists, followed by employees, the community and customers. These results suggest that these four stakeholder groups are among the most salient for companies in the CSR realm. These reporting practices of the companies in the study align with the findings of previous scholars who have also explored salience and reporting to stakeholders in other research contexts. For example, Snider et al. (2003) identify the four most salient stakeholder groups according to the information reported on the websites of Forbes Magazine's top 50 U.S. and top 50 multinational companies of nonU.S. origin. Their findings suggest that these four stakeholder groups include customers, employees, investors and community. Similarly, Sweeney and Coughlan (2008) observe that, even though some differences may exist among industries, most companies in the FTSE4Good index take a focused stakeholder view of CSR and concentrate their reporting efforts on employees, community and customers. Finally, Dong et al. (2014) investigate the influence of key stakeholder groups on the reporting of Chinese mining and mineral companies. Their findings suggest that international consumers are a new salient stakeholder in this country, while the institutional and political characteristics of China explain the lower salience of local communities and employees in their research context. Based on these findings, it appears that companies in Spain are currently reporting more intensely to those stakeholder groups that have traditionally been considered highly salient in the development of a successful CSR strategy (Elkington, 1994). On the contrary, regulators, media, partners and investors receive significantly less information in the CSR reporting of listed companies.

Nevertheless, the findings concerning the second research hypothesis of this study seem to suggest that companies are not evaluating the salience of stakeholders properly in the current context of the Spanish economy. More specifically, the findings suggest that the most salient stakeholders in terms of the generation of CSR reputation are investors, while companies still focus their CSR reports on information orientated to other traditional stakeholders whose claims are currently not as powerful, legitimate or urgent as the ones coming from their shareholders and creditors. Additionally, companies have responded to the latest pressures of the Spanish governmental and public opinion by communicating an increasing amount of legal information and information orientated to the media. However, the findings of the study suggest that this strategy is being counterproductive to the management of CSR reputation. We argue that the institutional, political and business characteristics of Spain after the Great Recession of 2007-2008 are playing a key role in the definition of stakeholders' salience and that companies operating in the country need to 
adapt to these new context in order to improve the benefits derived from their CSR activities and reporting to stakeholders.

For example, after the Great Recession and all the economic, legal and ethical flaws that were evidenced in the behaviour of Spanish companies and institutions (Matute et al., 2011), investors may meet the requirement for power, legitimacy and urgency better than the rest of the stakeholders explored in this paper. In this regard, investors have always been considered one of the most powerful stakeholder groups of a company (Mitchell et al., 1997). Even though the power of other stakeholders may change over time (Morf et al., 2013), the power of investors is much more stable because they control the most critical resource for the continued viability of the company: money. Additionally, in periods of low profitability and in situations of high debt, the economic demands of investors will take priority over the social demands of other stakeholder groups (Ullmann, 1985). This idea supports the legitimacy and urgency of investors' demands in periods of economic crisis, such as the one that the Spanish economy is currently facing. In this context, most of the measures and new laws that have been implemented by the Spanish government after the recession are orientated to improve the exercise of informative transparency to boost investors' confidence in different industries and heal the main weaknesses of companies, namely funding issues (Carballo, 2011). It is also important to highlight that our sample only includes listed companies, for which the salience of investors is quite high. When outside investors finance companies, they face a risk because the returns on their investments can even not materialize because the controlling shareholders or managers expropriate them (La Porta et al., 2000). Thus, investor protection turns out to be crucial in this context and justifies the salience of this stakeholder group in the specific case of listed companies. Corporate governance mechanisms (such as transparent financial and CSR reporting) can help in the protection of outside investors against expropriation by the insiders (La Porta et al., 2000).

The fact that investors are actually the stakeholders who receive the least amount of information through CSR reports might be justified by the existence of other communication channels that are more frequently used by companies to report CSR information to them. For example, it has been shown that companies now publish most of the information orientated to investors through their websites and annual financial reports instead of CSR reports, which are mostly orientated to the rest of stakeholder groups (Sweeney and Coughlan, 2008; Ki and Chung, 2011). Anyway, the findings of the study suggest that the salience of this stakeholder group is so high and relevant for the generation of CSR reputation that companies would benefit significantly from also including information to them in their CSR reporting.

On the contrary, our findings suggest that the demands of the rest of stakeholders (i.e., employees, customers, community, partners, activists, regulators and the media) are not always as powerful, legitimate or urgent as investors' claims in the current context of Spanish industries. Along this line, empirical findings by Elijido-Ten et al. (2010) suggest that the level of interdependence between the company and stakeholders plays a significant role in the definition of stakeholder power, legitimacy and urgency. Elijido-Ten et al. (2010) show that reporting to stakeholders is significantly more important in the cases when companies depend heavily on a stakeholder group for survival, that is, when there is a high 
interdependence relationship or the relationship is mainly dominated by stakeholders (Frooman, 1999). On the contrary, when the company has a low level of dependence on the stakeholder, the company does not need to be responsive to stakeholder demands and as so the importance of reporting to stakeholders is lower (Frooman, 1999).

For example, employees are found to fall under the company power relationship since they are more likely to depend on the company for their survival than the converse (Elijido-Ten et al., 2010). This idea is especially true in the Spanish context during and after the recession period. The Spanish unemployment rate, which fell from 22\% in 1994 to 8\% in 2007, reached 19\% by the end of 2009 (Bentolila and Cahuc, 2010) and is currently located at 23\% approximately. As a consequence of the Great Recession, millions of Spanish employees have been laid off, while among those who have hold on to their jobs, the contracts have become more precarious and many have experienced cuts in hours worked, wages and others benefits as companies seek to reduce labour costs in order to remain afloat (Verick, 2009). Additionally, the national government has implemented several measures to achieve labour market flexibility and companies have used these measures to continue offering temporary and precarious positions (Bentolila and Cahuc, 2010). Thus, employees' claims are very legitimate and urgent in Spain. However, this stakeholder group clearly lacks the power to influence the behaviour of companies and, as so, its salience is currently moderate to low.

The situation is slightly different in the case of customers' claims. Traditionally, the powerdependence relationship between customers and companies have fallen under the "stakeholder power" category (Elijido-Ten et al., 2010). Customers depend on the company for reasons such as the supply of goods/services and socio-economic progress. However, companies are dependent on this stakeholder group more so than it is on the company because of the stakeholder's ability to threaten the company's existence in terms of lost business and cash flows (Elijido-Ten et al., 2010). Thus, customers' claims have the power and legitimacy needed to be considered salient stakeholders. Nevertheless, the protection that the new commercial laws offer to Spanish customers after the recession justify that not significant problems have arisen in this area since their promotion and implementation (Represa, 2009; Gómez and Lyczkowska, 2014). Therefore, the demands of customers are not currently a priority on the public agenda and their urgency is subordinated to other priority issues such as unemployment, corruption or financial issues (Palau and Davesa, 2013).

Additionally, activists and the community may be perceived as secondary stakeholders who virtually have neither power nor legitimate claim against companies in the absence of any urgent event (Elijido-Ten et al., 2010). Thus, although their potential to threaten or cooperate with the company could range from low to high; without an urgency element present, neither the company nor activists or the community would depend on each other for survival (Mitchell et al., 1997). For example, it has been demonstrated that Spanish managers clearly perceive that they have community and social obligations, although they do not necessarily associate them with "business" activities (Spence and Lozano, 2000). They perceive that they are involved with them as citizens, in such a way that it is not their business' but their citizen's responsibility to satisfy those obligations (Spence and Lozano, 2000). Some managers admit to bringing their spiritual and religious beliefs to the 
workplace and using them as moral guidelines, but they are not necessarily associated with their professional life. This idea applies to many social and environmental issues that are not perceived as being of immediate urgency in Spanish companies (Spence and Lozano, 2000). For example, the Great Recession has evidenced the severity of social problems such as the solvency concerns of the Social Security System or the inequality of income distribution due to tax policies (Valle, 2015). Nevertheless, all the social pressure derived from these concerns is orientated to the Government, instead of the business sphere, as the main institution that should solve the instability of the Spanish social systems. According to these ideas, it seems that right now the relationship between companies and the community is one of low interdependence because activists and the community lack urgent claims to demand to companies (although they have urgent claims to demand to political and governmental institutions).

It is also generally agreed that suppliers and business partners are little likely to be able to change the behaviour of companies' owner-managers (Spence and Lozano, 2000). Thus, their power in the relationship with other companies is frequently low, even though the legitimacy and urgency of their claims might range from low to high (Elijido-Ten et al., 2010). This is especially true for the listed companies explored in this study because most of them are very big, consolidated and powerful companies in their industries. The size of these companies has significant consequences on the diversity and scale of their relationships with other partners, which means that they exercise a strategy power reflected in the scale of their economic resources and their corporate-wide planning capacity (Smith, 1999). In this context, the competitive strategy of big companies exert an upward and downward pressure upon partners, compelling a search for increased labour and capital productivity, reduced costs, etc (Smith, 1999). These ideas align with the findings of Spence and Lozano (2000), who observed that Spanish managers are highly individualist and, when participating in associations with other business partners, it is only making a financial contribution rather than a participatory one. This means that cooperation and communication between companies from the same industry are not integral, while if this communication were effective and intense, it would serve in helping to avoid many cases of corruption and unethical behaviour (Spence and Lozano, 2000). The findings of these scholars show that a $73 \%$ of the managers consulted in their study considered that business partners had no influence on the managers' decisions to respond to their CSR concerns.

Concerning regulators, reporting to this stakeholder group refers to the disclosure of information that demonstrates the compliance of companies with laws and their active position regarding legal dispositions. Accordingly, the payment of taxes on a regular basis, compliance with local laws and regulations, control for bribery and whistle-blowing activities in corporations or the description of policies concerning political lobbying and contributions fall into this CSR domain. The last financial crisis has had a strong impact in the Spanish Law System (Valle, 2015). Under recommendation of the European Union, the successive governments since 2008 until the end of 2015 have passed frequent "emergency legislation" that has regulated social rights, the Social Security System and the behaviour of companies in terms of unemployment benefits and retirement agreements (Valle, 2015). Thus, the Great Recession has proven that urgent reforms were needed in the Spanish Law System in order to assure that the same problems suffered during the crisis would not be repeated in the future. Consequently, in the current context Spanish regulators are also very powerful 
stakeholders as they have become the main source to force change in corporate behaviour (Spence and Lozano, 2000). Nevertheless, the fact that the adoption of legal reforms is compulsory for companies make scholars believe that legal compliance should not be considered part of the CSR of a company (Jones, 1980; Waldman et al., 2006). Rather, CSR should differentiate companies on the basis of their voluntary contributions to the community (Waldman et al., 2006). These ideas are in line with the CSR definition provided by the European Commission (2011), which refers to CSR as the "responsibility of enterprises for their impacts on society" (p. 6). In so defining the concept, the European Commission (2011) considers that CSR concerns "actions by companies over and above their legal obligations towards society and the environment" (p. 3). Based on these arguments, we can conclude that, although powerful and urgent, the demands of regulators might not be legitimate from a CSR point of view. Thus, regulators are "expectant stakeholders" (moderately salient stakeholders) because they possess only two of the attributes described by Mitchell et al. (1997) in their theoretical stakeholder framework.

Actually, the intensity of information currently reported to regulators in the CSR reports analysed in this study penalizes the CSR reputation of listed companies operating in Spain. In this regard, we have already highlighted the political and business corruption as well as financial scandals as some of the effects of the latest financial crisis in the country (Palau and Davesa, 2013). Thus, right now Spanish stakeholders are especially sensitive to legal issues and they are highly suspicious of corporate motivations to report on their legal compliance (Matute et al., 2011). Many times, this type of reporting is seen as a windowwashing strategy that only disguises the real purposes of the company that uses it (Laufer, 2003).

Something similar happens in the case of the CSR reporting to the media. This stakeholder group is one of the most powerful influencers of public opinion and business behaviour (Watts and Dodds, 2007). As suggested by Mitchell et al. (1997), the media are stakeholders who have "power over the company, whether or not they have valid claims or any claims at all and whether or not they wish to press their claims" (Mitchell et al., 1997, p. 859). Nowadays, companies need to establish good relationships with the media because, otherwise, they can face bad publicity or be unnoticed in society. Thus, the media has substantial power and managers give them priority because of the urgency imposed by reputation demands. This idea is even clearer in a recession period because companies need to recover stakeholders' trust in their management practices and they need as much support from the media as possible. Nevertheless, and very similarly to regulators, media's claims may lack legitimacy in the CSR sphere and this stakeholder group might not possess enough attributes as to be considered a "definitive stakeholder group" (Elijido-Ten et al., 2010). Previous scholars have already demonstrated that using press releases to communicate the CSR commitment of companies has negative impacts on their legitimation in society (Aaert and Cormier, 2009). Specifically, Aaert and Cormier (2009) empirically demonstrate that environmental legitimacy is significantly and positively affected by the quality of the economic-based segments of annual report environmental reporting and by reactive environmental press releases, but not by proactive press releases. Thus, as suggested by Elijido-Ten et al. (2010), the media can be considered a secondary stakeholder group with low interdependence with companies nowadays. 
As far as the negative impact of information orientated to the media in the relationship between reporting to stakeholders and CSR reputation, once again we have to refer to the public perception of media communication as a window-washing technique that results in increased social cynicism and mistrust (Jahdi and Acikdilli, 2009). Thus, a high level of intensity of reporting to the media is detrimental to the CSR reputation of companies because stakeholders can easily perceive this type of reporting as only a public relations initiative. For example, after the numerous political and financial scandals that have occurred in Spain in the 1990s and the beginning of the $21^{\text {st }}$ century, corruption has become one of the main concerns of Spanish public opinion (Palau and Davesa, 2013). When the number of news stories on political corruption increased, the percentage of citizens that considered corruption as one of the most important problems in Spain also increased (Palau and Davesa, 2013). Thus, the media has helped create a vicious circle of lack of confidence in companies, which reinforce citizens' dissatisfaction and mistrust in them (Villoria and Jiménez, 2012). In this context, any trial of companies to reverse the situation by communicating positive things to the media in order for this stakeholder to spread favourable corporate news in not adequately understood and the consequences are just the opposite to the expectations of those companies.

\section{Conclusions, practical implications and future lines of research}

In this paper, we explore the relationship that exists between reporting to stakeholders and the CSR reputation of several companies listed in the Spanish "MercoEmpresas Responsables" index. Based on stakeholder theory, scholars have traditionally concentrated on analysing the corporate motivations for reporting information to stakeholders, the relationships among reporting to stakeholders, financial and CSR performance or the effects of financial performance on corporate reputation (Hasseldine et al., 2005). However, little previous empirical research has explored the direct relationship between reporting to stakeholders and CSR reputation, especially when the intensity of reporting to different stakeholder groups is considered.

In summary, the findings reported in this paper suggest that for the generation of CSR reputation it is not enough for a company to include large amounts of information in CSR reports (i.e., showing an active strategic posture towards CSR activities). On the contrary, properly understanding the benefits of reporting to stakeholders in terms of CSR reputation would imply correctly assessing stakeholder salience by paying particular attention to their power, legitimacy and urgency.

The findings are robust and demonstrate that the current global intensity of reporting to stakeholders does not determine companies' CSR reputation in a definitive way. First, there are other corporate characteristics that are more relevant to stakeholders than CSR reports, such as size, financial performance and industry. Second, compensation effects exist. In this regard, while reporting information related to preserving shareholder rights, honestly and transparently informing on economic issues, avoiding insider trading and strengthening corporate governance are closely related to a positive CSR reputation, diverting the attention of readers to legal compliance and media issues may be detrimental to the CSR reputation. Third, other information contained in CSR reports and referred to other stakeholders, such as employees, customers, activists, community or partners, is simply 
insignificant in terms of the generation of positive CSRR in the context analysed. As it has been discussed in the paper previously, many of these findings may be specific to the institutional, political and business characteristics of Spain after the Great Recession of 2007-2008.

These findings have significant implications for the management of CSR reputation and reporting to stakeholders in companies. In terms of managing the CSR reputation, companies should establish regular mechanisms for monitoring stakeholder power, legitimacy and urgency over time. As suggested by Moneva et al. (2007) when talking about the integration of stakeholder management into the company, "defining corporate values without enabling communication and effective dialogue with the stakeholders could generate an organisational culture distant from the latter's expectations and needs (Gray, 2001; Leonard and Cronan, 2005; Palanisamy, 2005)" (p. 88). In this regard, stakeholder expectations and demands change significantly over time (Kent and Chan, 2003). Similarly, shifts in influence and power stemming from different stakeholders are also frequent (Morf et al., 2013). In establishing these monitors, companies would always have updated information on the CSR activities that imply a better CSR reputation. They would also have a better understanding of the types of information that they should include in CSR reports if their purpose when publishing these documents is to improve their intangible assets, such as their CSR reputation.

At present, the findings reported in this paper suggest that companies publishing CSR reports as a means to improve their CSR reputation can benefit from taking four strategic decisions. First, they should give greater priority to reporting to investors in their CSR reports. Even though information is extensively provided for investors in other documents regularly published by companies (e.g., annual reports), the salience of economic responsibilities nowadays makes this type of information highly sensitive and companies would benefit from including this information also in their CSR reports. Secondly, companies should also reduce the amount of detail in explaining their compliance with the law and their efforts to ensure ethical behaviour in their management decisions. As previously explained in this paper, reporting extensive information on the company's compliance with legal requirements can be understood as a greenwashing strategy and lead to mistrust and a worse CSR reputation. Thirdly, they should reduce the information provided to the media in CSR reports, because the information reported to this stakeholder group is also counterproductive in terms of the generation of CSR reputation. This does not mean that companies should not provide information to the media at all. However, the findings suggest that CSR reports are not the best communication tool to build a relationship with this stakeholder group. Actually, managers should be especially careful when reporting information to regulators and the media, because the intensity of this reporting could even nullify the positive impact of the information orientated towards investors on CSR reputation. Fourthly, in the case that companies need to prioritize the interests of stakeholders (e.g., they do not have enough resources to comply with all the stakeholders' demands), the least harmful strategy would be to reduce the investment and/or reporting of CSR activities orientated towards employees, customers, activists, community or partners. The information provided to these stakeholder groups does not have any significant impact on CSR reputation. 
Nevertheless, this study is not without limitations and we consider that future studies should take them into account to improve the research on the reporting-reputation link. First, some scholars have recently confirmed that there is a problem of endogeneity in the relationship between reporting to stakeholders and reputation (Michelon, 2011). This relationship is bidirectional, so it is not only that reporting to stakeholders influences the way in which society perceives corporate reputation, but also that this perception determines the activities undertaken and communicated by companies in the CSR domain (Michelon, 2011). Accordingly, future scholars should devote their attention to the direction of the relationship between reporting to stakeholders and reputation to develop models that could augment the academic knowledge concerning the CSR-reputation link. Several scholars have also demonstrated that when analysing reporting to stakeholders, the quality of the information provided is also relevant (Piechocki, 2004; Hasseldine et al., 2005; de los Ríos et al., 2012). Future lines of research should provide more sophisticated ways of evaluating reporting to stakeholders, also including the information reported on websites, in annual reports and/or in any other documents regularly published by companies. In addition to this, it is possible that some of the findings reported in this paper were biased by an economic "halo" effect in the "MercoEmpresas Responsables" index that could be similar to the "halo" effect reported for the Fortune index (Frixell and Wang, 1994). However, the method implemented in this paper did not allow us to corroborate this idea because we could not use control groups to measure CSR reputation. Thus, future scholars should replicate the study using different samples and controlling the existence of this economic "halo" effect. Additional control variables that should be incorporated into studies on the reporting-reputation link include stakeholder power, legitimacy and urgency. Based on the premises of stakeholder theory, we have provided numerous arguments that suggest the incorporation of these concepts into empirical studies. However, we did not measure these variables and this fact represents a significant limitation of our paper. Finally, it is noticeable that the companies that are represented in the "MercoEmpresas Responsables" index are not all the companies operating in Spain. Thus, the findings presented in this paper cannot be generalized to a larger amount of companies. This being so, it would be necessary for future scholars to use larger samples to determine whether the findings in this paper are also representative of the reporting to stakeholders and CSR reputation of other companies with different characteristics from the companies included in the "MercoEmpresas Responsables" index. This last idea is supported by the role of context that has been long defended in academic literature (Smith et al., 2005; Elijido-Ten et al., 2010; Dong et al., 2014).

\section{References}

Aerts, W. and Cormier, D. (2009), "Media legitimacy and corporate environmental communication", Accounting, Organizations and Society, Vol. 34 No. 1, pp. 1-27.

Alonso, M.M. and Bremser, K. (2013), "Strategic responses of the Spanish hospitality sector to the financial crisis", International Journal of Hospitality Management, Vol. 32, pp. 141148.

An, Y.; Davey, H. and Eggleton, I.R.C. (2011), "Towards a comprehensive theoretical framework for voluntary IC disclosure", Journal of Intellectual Capital, Vol. 12 No. 4, pp. 571585. 
Bakeman, R. and Gottman, J.M. (1986), Observing Interaction: An Introduction to Sequential Analysis, Cambridge University Press, Cambridge.

Bayoud, N.S. and Kavanagh, M. (2012), "Corporate social responsibility disclosure: Evidence from Lybian managers", Global Journal of Business Research, Vol. 6 No. 5, pp. 73-83.

Bentolila, S. and Cahuc, P. (2010), "Unemployment and temporary jobs in the crisis: comparing France and Spain", working paper FEDEA, vol. 7, pp. 1-35.

Bird, R.; Hall, A.D.; Moment, F. and Reggiani, F. (2007), "What corporate social responsibility activities are valued by the market?", Journal of Business Ethics, Vol. 76, pp. 189-206.

Brammer, S.J. and Pavelin, S. (2004), "Building a good reputation", European Management Journal, Vol. 22 No. 6, pp. 704-713.

Bravo, R.; Matute, J. and Pina, J.M. (2012): "Corporate social responsibility as a vehicle to reveal the corporate identity: A study focused on the websites of Spanish financial entities", Journal of Business Ethics, Vol. 107 No. 2, pp. 129-146.

Carballo, F. (2011): "Causes and consequences of the Spanish economic crisis: Why the recovery is taken so long?", Panoeconomicus, Vol. 58 No. 3, pp. 309-328.

Carroll, A.B. (1979), "A three-dimensional conceptual model of corporate performance", The Academy of Management Review, Vol. 4 No. 4, pp. 497-505.

Castelo, M. and Lima, L. (2006), "Corporate social responsibility and resource-based perspectives", Journal of Business Ethics, Vol. 69, pp. 111-132.

Cegarra, J. and Martínez, A. (2009): "Linking corporate social responsibility with admiration through organizational outcomes", Social Responsibility Journal, Vol. 5 No. 4, pp. 499-511.

Chakravarthy, B. (1986), "Measuring Strategic Performance", Strategic Management Journal, pp. 437-458.

Chan, M.C.; Watson, F. and Woodliff, D. (2014), "Corporate governance quality and CSR disclosures", Journal of Business Ethics, Vol. 125, pp. 59-73.

Chatterjee, S. and Hadi, A.S. (2012), Regression Analysis by Example (5th ed), John Wiley \& Sons, New Jersey, NY.

Clarkson, M. E. (1995), "A stakeholder framework for analyzing and evaluating corporate social performance", Academy of Management Review, Vol. 20 No. 1, pp. 92-117.

Deegan, C. (2002), "The legitimizing effect of social and environmental disclosures - A theoretical foundation", Accounting, Auditing and Accountability Journal, Vol. 15 No. 3, pp. 282-311.

Deegan, C. and Unerman, J. (2011), Financial Accounting Theory (2nd ed), McGraw-Hill Higher Education, Berkshire, UK.

Delgado, J.B.; Quevedo, E. and Díez, J.M. (2013), "The impact of corporate reputation on firm risk: A panel data analysis of Spanish quoted firms", British Journal of Management, Vol. 24 No. 1, pp. 1-20.

de los Ríos, A.; Ruiz, M.; Tirado, P. and Carbonero, M. (2012), "Una aproximación a la relación entre información sobre la responsabilidad social orientada al cliente y la reputación corporativa de las entidades financieras españolas", Cuadernos de Economía y Dirección de la Empresa, Vol. 15, pp. 130-140.

Dong, S.; Burritt, R. and Qan, W. (2014), "Salient stakeholders in corporate social responsibility reporting by Chinese mining and minerals companies", Journal of Cleaner Production, Vol. 84, pp. 59-69.

Du, S.; Bhattacharya, C.B. and Sen, S. (2010), "Maximizing business returns to Corporate Social Responsibility (CSR): The role of CSR communication", International Journal of Management Reviews, Vol. 12 No. 1, pp. 8-19. 
Elijido-Ten, E.; Kloot, L. and Clarkson, P. (2010), "Extending the application of stakeholder influence strategies to environmental disclosures. An exploratory study from a developing country". Accounting, Auditing \& Accountability Journal, Vol. 23, No. 8, pp. 1032-1059.

Elkington, J. (1994), "Towards the suitable corporation: Win-win-win business strategies for sustainable development", California Management Review, Vol. 36 No. 2, pp. 90-100.

Éltetó, A. (2011), "The economic crisis and its management in Spain", Eastern Journal of European Studies, Vol. 2 No. 1, pp. 41-55.

European Commission (2011), "A renewed EU strategy 2011-2014 for Corporate Social Responsibility", working paper COM (2011) 681 final.

Fernández, J.L. and Luna, L. (2007), "The creation of value through corporate reputation", Journal of Business Ethics, Vol. 76, pp. 335-346.

Fernández, J.L.; Luna, L. and Baraibar, E. (2012), "Can corporate reputation protect companies' value? Spanish evidence of the 2007 financial crash", Corporate Reputation Review, Vol. 15 No. 4, pp. 228-239.

Fernández-Feijoo, B.; Romero, S. and Ruiz, S. (2014), "Effect of stakeholders' pressure on transparency of sustainability reports within the GRI framework", Journal of Business Ethics, Vol. 122, pp. 53-63.

Fombrun, C.J. and Shanley, M. (1990), "What's in a name? Reputation building and corporate strategy", Academy of Management Journal, Vol. 33 No. 2, pp. 233-258.

Fombrun, C.J.; Gardberg, N.A. and Barnett, M.L. (2000), "Opportunity platforms and safety nets: Corporate citizenship and reputational risk", Business and Society Review, Vol. 105 No. 1, pp. 85-106.

Freeman, R.E. (1984), Strategic Management: A Stakeholder Approach, Pittman, Boston, MA.

Friedman, M. (1970), "Social responsibility of business is to increase its profit", New York Times Magazine, pp. 122-126.

Frooman, J. (1999), "Stakeholder influence strategies", Academy of Management Review, Vol. 24 No. 2, pp. 191-205.

Fryxell, G.E. and Wang, J. (1994), "The Fortune corporate 'reputation' index: Reputation for what?", Journal of Management, Vol. 20, pp. 1-14.

Gamerschlag, R.; Möller, K. and Verbeeten, F. (2011), "Determinants of voluntary CSR disclosure: Empirical evidence from Germany", Review of Managerial Science, Vol. 5, pp. 233-262.

Gómez, F. and Lyczkowska, K. (2014), "Spanish courts, the Court of Justice of the European Union, and consumer law", InDret: Revista Para el Análisis del Derecho, vol. 4, pp. 1-34.

Gram, M. (2007), "Children as co-decision makers in the family? The case of family holidays", Young Consumers, Vol. 8 No. 1, pp. 19-28.

Gray, R.; Kouhy,R. and Lavers, S. (1995), "Corporate social and environmental reporting: A review of the literature and a longitudinal study of UK disclosure", Accounting, Auditing and Accountability Journal, Vol. 8, pp. 47-77.

Guthrie, J. and Abeysekera, I. (2006), "Content analysis of social, environmental reporting: What is new?", Journal of Human Resource Costing \& Accounting, Vol. 10 No. 2, pp. 114126.

Hart, T.A. and Sharfman, M. (2012), "Assessing the concurrent validity of the revised Kinder, Lydenberg, and Domini corporate social performance indicators", Business and Society, Vol. 9, pp. online first. 
Hasseldine, J.; Salama, A.I. and Toms, J.S. (2005), "Quantity versus quality: The impact of environmental disclosures on the reputations of UK PIcs", The British Accounting Review, Vol. 37, pp. 231-248.

Hillman, A.J. and Keim, G.D. (2001), "Shareholder value, stakeholder management, and social issues: What's the bottom line?", Strategic Management Journal, Vol. 22, pp. 125139.

Islam, M.A. and Deegan, C. (2008), "Motivations for an organisation within a developing country to report social responsibility information: Evidence from Bangladesh", Accounting, Auditing \& Accountability Journal, Vol. 21 No. 6, pp. 850-874.

Jahdi, K.S. and Acikdilli, G. (2009), "Marketing communications and corporate social responsibility (CSR). Marriage of convenience or shotgun wedding", Journal of Business Ethics, Vol. 88, pp. 103-113.

Jones, T.M. (1980), "Corporate social responsibility revisited, redefined", California Management Review, Vol. 22 No. 3, pp. 59-67.

Kent, P. and Chan, C. (2003), "Application of stakeholder theory to the quantity and quality of Australian voluntary corporate environmental disclosures", paper presented at the AFAANZ Annual Conference, 6-8 July, Brisbane, Australia, available at SSRN 447901 (accessed 01 May 2015).

Ki, E. and Chung, J.Y. (2011), "Corporate web pages as a key communication channel for financial publics", Public Relations Journal, Vol. 5 No. 4, pp. 1-22.

Krippendorf, K. (1980), Content Analysis: An Introduction to its Methodology, Sage Publications, Beverly Hills, CA.

Lii, Y. and Lee, M. (2012), "Doing right leads to doing well: When the type of CSR and reputation interact to affect consumer evaluations of the firm", Journal of Business Ethics, Vol. 105, pp. 69-81.

La Porta, R.; Lopez-de-Silanes, F.; Shleifer, A. and Vishny, R. (2000), "Investor protection and corporate governance", Journal of Financial Economics, Vol. 58 No. 1, pp. 3-27.

Laufer, W.S. (2003), "Social accountability and corporate greenwashing", Journal of Business Ethics, Vol. 43 No. 3, pp. 253-261.

Llena, F.; Monera, J.M. and Hernández, B. (2007), "Environmental disclosure and compulsory accounting standards: The case of Spanish annual reports", Business Strategy and the Environment, Vol. 16, pp. 50-63.

Luna, L. and Fernández, J.L. (2010): "Corporate social reporting for different audiences: The case of multinational corporations in Spain", Corporate Social Responsibility and Environmental Management, Vol. 17, pp. 272-283.

Maignan, I. and Ferrell, O.C. (2004), "Corporate social responsibility and marketing: An integrative framework", Journal of the Academy of Marketing Science, Vol. 32 No. 1, pp. 319.

Matute, J.; Bravo, R. and Pina, J.M. (2011), "The influence of corporate social responsibility and price fairness on customer behaviour: Evidence from the financial sector", Corporate Social Responsibility and Environmental Management, Vol. 18 No. 6, pp. 317-331.

McWilliams, A. and Siegel, D. (2001), "Corporate social responsibility: A theory of the firm perspective", Academy of Management Review, Vol. 26, pp. 117-128.

Melo, T. and Garrido, Á. (2012), "Corporate reputation: A combination of social responsibility and industry", Corporate Social Responsibility and Environmental Management, Vol. 19, pp. 11-31. 
Michelon, G. (2011), "Sustainability disclosure and reputation: A comparative study", Corporate Reputation Review, Vol. 14 No. 2, pp. 79-96.

Michelon, G. and Parbonetti, A. (2012), "The effect of corporate governance on sustainability disclosure", Journal of Management \& Governance, Vol. 16, pp. 477-509.

Milne, M.J. and Adler, R.W. (1999), "Exploring the reliability of social and environmental disclosures content analysis", Accounting, Auditing and Accountability Journal, Vol. 12 No. 2, pp. 237-256.

Milne, M.J. and Patten, D.M. (2002), "Securing organizational legitimacy. An experimental decision case examining the impact of environmental disclosure", Accounting, Auditing \& Accountability Journal, Vol. 15 No. 3, pp. 372-405.

Misha, S. and Suar, D. (2010), "Does corporate social responsibility influence firm performance of Indian companies?", Journal of Business Ethics, Vol., 95, pp. 571-601.

Mitchell, R.K.; Agle, B.R. and Wood, D.J. (1997), "Toward a theory of stakeholder identification and salience: Defining the principle of who and what really counts", The Academy of Management Journal, Vol. 22 No. 4, pp. 853-886.

Moneva, J.M.; Rivera, J.M. and Muñoz, M.J. (2007), "The corporate stakeholder commitment and social and financial performance", Industrial Management \& Data Systems, Vol. 107 No. 1, pp. 84-102.

Morf, D.; Flesher, D.L.; Hayek, M.; Pane, S. and Hayek, C. (2013), "Shifts in corporate accountability reflected in socially responsible reporting: A historical review", Journal of Management History, Vol. 19 No. 1, pp. 87-113.

Nasi, J.; Nasi, S.; Phillips, N. and Zyglidopoulos, S. (1997), "The evolution of corporate social responsiveness - An exploratory study of Finnish and Canadian forestry companies", Business \& Society, Vol. 38 No. 3, pp. 296-321.

Neüendorf, K.A. (2002), The Content Analysis Guidebook, Sage Publications, Thousand Oaks, CA.

Neu, D.; Warsame, H. and Pedwell, K. (1998), "Managing public impressions: Environmental disclosures in annual reports", Accounting Organizations and Society, Vol. 25, pp. 265-282.

Orlitzky, M.; Schmidt, F.L. and Rynes, S.L. (2003), "Corporate social and financial performance: A meta-analysis", Organization Studies, Vol. 24 No. 3, pp. 403-441.

Palau, A.M. and Davesa, F. (2013), "The impact of media coverage of corruption on Spanish public opinion", Revista Española de Investigaciones Sociológicas, Vol. 144 No. 1, pp. 97-124. Pérez, A. (2015); "Corporate reputation and CSR reporting to stakeholders: Gaps in the literature and future lines of research", Corporate Communications: An International Journal, Vol. 20 No. 1, pp. 11-29.

Perrault, W.D. and Leigh, L.E. (1989), "Reliability of nominal data based on qualitative judgments", Journal of Marketing Research, Vol. 26 No. 2, pp. 135-148.

Pfeifer, J. and Salancik, G. (1978), The External Control of Organizations: A Resource Dependence Perspective, Harper \& Row, New York, NY.

Piechocki, R. (2004), "Industry survey: Transparency of annual sustainability reports", Corporate Reputation Review, Vol. 7 No. 2, pp. 107-123.

Prado, J.M.; Gallego, I. and García, I.M. (2009), "Stakeholder engagement and corporate social responsibility reporting: The ownership structure effect", Corporate Social Responsibility and Environmental Management, Vol. 16, pp. 94-107.

Represa, M.S. (2009), "Adaptation and reform of consumer law. Recent evolution of this sector in the Spanish legal system", Acta Universitatis Lucian Blaga, vol. 23. 
Roberts, R.W. (1992), "Determinants of corporate social responsibility disclosure: An application of stakeholder theory", Accounting, Organizations and Society, Vol. 17 No. 6, pp. 595-612.

Roberts, P.W. and Dowling, G.R. (2002), "Corporate reputation and sustained financial performance", Strategic Management Journal, Vol. 23, pp. 1077-1093.

Schultz, M.; Hatch, M.J. and Larsen, M.J. (2000), The Expressive Organization: Linking Identity, Reputation, and the Corporate Brand, Oxford University Press, Oxford.

Sharfman, M. (1996), "The construct validity of the Kinder, Lydenberg \& Domini social performance ratings data", Journal of Business Ethics, Vol. 15 No. 3, pp. 287-296.

Smith, P. (1999), "Exclusion and disarticulation: The transport and general workers' union in the road haulage industry, 1979-1998", British Journal of Industrial Relations, Vol. 37 No. 4, pp. 615-636.

Smith, J.; Adhikarj, A. and Tondkar, R.H. (2005), "Exploring differences in social disclosures internationally: A stakeholder perspective", Journal of Accounting and Public Policy, Vol. 24, pp. 123-151.

Snider, J.; Hill, R.P. and Martin, D. (2003), "Corporate social responsibility in the $21^{\text {st }}$ century: A view from the world's most successful firms", Journal of Business Ethics, Vol. 48, pp. 175187.

Soppe, A.; Schauten, M.; Soppe, J. and Kaymak, U. (2011), "Corporate social responsibility reputation (CSRR). Do companies comply with their raised CSR expectations?", Corporate Reputation Review, Vol. 144, pp. 300-323.

Spence, L.J. and Lozano, J.F. (2000), "Communicating about ethics with small firms: Experiences from the U.K. and Spain", Journal of Business Ethics, Vol. 27 No. 1, pp. 43-53.

Surroca, J., Tribo, J.A. and Waddock, S. (2010), "The role of intangible resources in explaining the relationship between corporate responsibility and financial performance", Strategic Management Journal, Vol. 31, pp. 463-490.

Suttipun, M. and Stanton, P. (2012), "Making or not making environmental disclosures in Thailand", International Journal of Business and Social Science, Vol. 3 No. 9, pp. 73-81.

Sweeney, L. and Coughlan, J. (2008), "Do different industries report corporate social responsibility differently? An Investigation through the lens of stakeholder theory", Journal of Marketing Communications, Vol. 14, No. 2, pp. 113-124.

Thorne, D.; Ferrell, O. and Ferrell, C. (2003), Business and Society: A Strategic Approach to Corporate Citizenship. Houghton Mifflin Company, Boston.

Toms, J.S. (2000), Environmental Management, Environmental Accounting and Financial Performance, CIMA, London.

Toms, J.S. (2002), "Firm resources, quality signals and the determinants of corporate environmental reputation: Some UK evidence", British Accounting Review, Vol. 34 No. 3, pp. 257-282.

Ullmann, A.A. (1985), "Data in search of a theory: A critical examination of the relationships among social performance, social disclosure, and economic performance of U.S. firms", Academy of Management Review, Vol. 10, pp. 540-557.

Valle, J.M.D. (2015), "Post-crisis social rights and social security law in Spain", Spanish Labour Law and Employment Relations Journal, Vol. 4 No. 1-2, pp. 55-63.

van der Laan, J.; Adhikari, A. and Tondkar, R.H. (2005), "Exploring differences in social disclosures internationally; A stakeholder perspective", Journal of Accounting and Public Policy, Vol. 24, pp. 123-151. 
Verick, S. (2009), "Who is hit hardest during a financial crisis? The vulnerability of young men and women to unemployment in an economic downturn", working paper, IZA Discussion Papers, No. 4359.

Waddock, S.A. and Graves, S.B. (1997), "Quality of management and quality of stakeholder relations", Business \& Society, Vol. 36 No. 3, pp. 250-279.

Waldman, D.A.; de Luque, M.S.; Washburn, N. and House, R.J. (2006), "Cultural and leadership predictors of corporate social responsibility values of top management: A GLOBE study of 15 countries", Journal of International Business Studies, Vol. 37 No. 6, pp. 823-837. Watts, D.J. and Dodds, P.S. (2007), "Influentials, networks, and public opinion formation", Journal of Consumer Research, Vol. 34 No. 4, pp. 441-458.

Wilmshurst, T.D. and Frost, G.R. (2000), "Corporate environmental reporting: A test of legitimacy theory", Accounting, Auditing and Accountability Journal, Vol. 13, pp. 10-25. 
Table 1

\section{Stakeholder groups and items of reporting to stakeholders}

\begin{tabular}{|c|c|c|}
\hline $\begin{array}{l}\text { Stakeholder } \\
\text { groups }\end{array}$ & Items & References \\
\hline Employees & $\begin{array}{l}\text { 1. Training and development } \\
\text { 2. Health and safety } \\
\text { 3. Equal opportunities } \\
\text { 4. Diversity } \\
\text { 5. Reconciliation of work and family life } \\
\text { 6. Social benefits (good retirement benefits, profit sharing, and } \\
\text { participation in the property of the company, among others) } \\
\text { 7. Freedom of association, collective bargaining and complaint } \\
\text { procedures } \\
\text { 8. Formal representation in decision-making } \\
\text { 9. Employee relations, communication and dialogue mechanisms } \\
\text { 10. Regular evaluation of employee satisfaction } \\
\text { 11. Policy of remuneration, compensation and rewards } \\
\text { 12. Job creation and stability }\end{array}$ & $\begin{array}{l}\text { Maignan and Ferrell, 2004; } \\
\text { Brammer and Pavelin, } \\
\text { 2004; Bird et al., 2007; } \\
\text { Melo and Garrido, } 2012\end{array}$ \\
\hline Customers & $\begin{array}{l}\text { 1. Competitive prices and payment conditions } \\
\text { 2. High product quality } \\
\text { 3. High innovation and accessibility } \\
\text { 4. Product health and safety } \\
\text { 5. Development of products to meet the special needs of the } \\
\text { disadvantaged } \\
\text { 6. Confidentiality } \\
\text { 7. Standards and voluntary codes for advertising and marketing } \\
\text { practices } \\
\text { 8. Transparency in advertising and marketing practices } \\
\text { 9. Customer relations, communication and dialogue mechanisms } \\
\text { 10. Regular evaluation of customer satisfaction } \\
\text { 11. CSR initiatives in collaboration with customers }\end{array}$ & $\begin{array}{l}\text { Maignan and Ferrell, 2004; } \\
\text { Bird et al., 2007; Misha and } \\
\text { Suar, 2010; Soppe et al., } \\
\text { 2011; Michelon, 2011; } \\
\text { Melo and Garrido, 2012; de } \\
\text { los Ríos et al., } 2012\end{array}$ \\
\hline Investors & $\begin{array}{l}\text { 1. Shareholder rights } \\
\text { 2. Formal representation in decision-making } \\
\text { 3. Investor relations, communication and dialogue mechanisms } \\
\text { 4. Regulatory mechanisms for prohibiting insider trading } \\
\text { 5. Rules to strengthen auditor independence } \\
\text { 6.Provision of all required information to credit rating agencies }\end{array}$ & Misha and Suar, 2010 \\
\hline Community & $\begin{array}{l}\text { 1. Environmental policy, systems and performance } \\
\text { 2. Social and charitable contribution } \\
\text { 3. Educational and cultural contribution } \\
\text { 4. Economic development programs } \\
\text { 5. Human rights } \\
\text { 6. Contribution to future generations } \\
\text { 7. Having a foundation } \\
\text { 8. Consultation with community leaders to know about emerging } \\
\text { issues }\end{array}$ & $\begin{array}{l}\text { Maignan and Ferrell, 2004; } \\
\text { Brammer and Pavelin, } \\
\text { 2004; Bird et al., 2007; } \\
\text { Misha and Suar, 2010; } \\
\text { Michelon, 2011; Melo and } \\
\text { Garrido, } 2012\end{array}$ \\
\hline Regulators & $\begin{array}{l}\text { 1. Payment of taxes on a regular and continuing basis } \\
\text { 2. Compliance with local laws and regulations } \\
\text { 3. Bribery and whistle-blowing programs } \\
\text { 4. Description of policies to political lobbying and contributions }\end{array}$ & $\begin{array}{l}\text { Misha and Suar, 2010; } \\
\text { Soppe et al., } 2011\end{array}$ \\
\hline
\end{tabular}


1. Policy to ensure ethical and friendly procurement at partner facilities

2. Policy on restrictions on the use of child labor, sweat shop and violation of human rights at partner facilities

3. Inspection of partners facilities for health, safety and environmental aspects

Misha and Suar, 2010; (also

Partners

4. Policy for social accountability or sustainable reporting by

includes a new item: \#8) partners

6. Equal opportunities when establishing alliances

7. Policy to pay and receive competitive market prices timely to/from partners

8. CSR initiatives in collaboration with partners

1. Employment volunteer activities and donation programs

2. Partnerships with nongovernmental and community

Maignan and Ferrell, 2004;

Activists organizations, government agencies and other industry groups

Misha and Suar, 2010 dedicated to CSR causes

Media 1. Regular publication of financial and non-financial information

2. Management of relationships with the media

new items 
Table 2

Descriptive statistics and correlation matrix

\begin{tabular}{|c|c|c|c|c|c|c|c|c|c|c|c|c|c|c|c|c|c|}
\hline Variable & mean & st. dev & $\min$ & $\max$ & 1 & 2 & 3 & 4 & 5 & 6 & 7 & 8 & 9 & 10 & 11 & 12 & 13 \\
\hline 1. CSRR & 8.34 & 0.30 & 8.00 & 9.21 & - & & & & & & & & & & & & \\
\hline 2. Global reporting & 3.46 & 1.13 & 0.88 & 6.16 & $0.29^{c}$ & - & & & & & & & & & & & \\
\hline 3. Employees & $0.64^{d}$ & 0.20 & 0.00 & 1.00 & 0.14 & $0.66^{c}$ & - & & & & & & & & & & \\
\hline 4. Customers & $0.42^{d}$ & 0.21 & 0.00 & 0.91 & 0.14 & $0.63^{c}$ & $0.46^{c}$ & - & & & & & & & & & \\
\hline 5. Investors & $0.17^{d}$ & 0.24 & 0.00 & 1.00 & $0.48^{c}$ & $0.63^{c}$ & $0.33^{c}$ & $0.25^{b}$ & - & & & & & & & & \\
\hline 6. Community & $0.60^{d}$ & 0.18 & 0.13 & 0.88 & $0.25^{b}$ & $0.63^{c}$ & $0.47^{c}$ & $0.36^{c}$ & $0.25^{b}$ & - & & & & & & & \\
\hline 7. Regulators & $0.32^{d}$ & 0.17 & 0.00 & 1.00 & 0.09 & $0.64^{c}$ & $0.53^{c}$ & $0.25^{b}$ & $0.44^{c}$ & $0.38^{c}$ & - & & & & & & \\
\hline 8. Partners & $0.27^{d}$ & 0.19 & 0.00 & 0.88 & $0.25^{b}$ & $0.55^{c}$ & $0.27^{b}$ & $0.47^{c}$ & $0.28^{b}$ & $0.39^{c}$ & $0.29^{c}$ & - & & & & & \\
\hline 9. Activists & $0.74^{d}$ & 0.31 & 0.00 & 1.00 & 0.17 & $0.53^{c}$ & 0.18 & $0.39^{c}$ & $0.25^{b}$ & $0.17^{a}$ & 0.12 & 0.14 & - & & & & \\
\hline 10. Media & $0.31^{d}$ & 0.36 & 0.00 & 1.00 & -0.03 & $0.43^{c}$ & 0.10 & 0.02 & 0.14 & $0.22^{b}$ & 0.04 & 0.05 & 0.04 & - & & & \\
\hline 11. Age & 45.06 & 29.36 & 3.00 & 131.00 & 0.06 & $0.20^{\mathrm{a}}$ & 0.09 & $0.28^{b}$ & 0.17 & 0.18 & 0.05 & $0.22^{b}$ & 0.05 & 0.00 & - & & \\
\hline 12. Size & 8.40 & 1.99 & 4.16 & 12.56 & $0.40^{c}$ & $0.26^{b}$ & 0.01 & 0.16 & $0.29^{c}$ & $0.25^{b}$ & 0.14 & 0.06 & 0.08 & $0.21^{b}$ & 0.17 & - & \\
\hline 13. ROA & 0.06 & 0.09 & -0.13 & 0.49 & 0.02 & -0.11 & -0.07 & -0.18 & -0.02 & -0.15 & -0.02 & 0.08 & 0.00 & -0.13 & -0.01 & $-0.27^{b}$ & - \\
\hline
\end{tabular}

${ }^{a}{ }^{b}$ and ${ }^{c}$ denote significance at the $90 \%, 95 \%$ and $99 \%$ level of confidence, respectively

${ }^{d}$ We implemented a means comparison test to identify significant differences in the intensity of reporting to different stakeholder groups. Findings showed the following ranking of intensities: (1) activists; (2) employees and community; (3) customers; (4) regulators, media and partners; (5) investors 
Table 3

Regression results: Model 1

\begin{tabular}{|c|c|c|c|}
\hline Variables & (1a) & (1b) & (1c) \\
\hline Global reporting & $0.08[0.29]^{* * *}$ & $0.06[0.22]^{*}$ & $0.03[0.10]$ \\
\hline Age & & $0.00[-0.04]$ & $0.00[-0.02]$ \\
\hline Size & & $0.06[0.39]^{* *}$ & $0.05[0.36]^{* *}$ \\
\hline ROA & & $0.48[0.15]$ & $0.62[0.19]^{*}$ \\
\hline Industry: & & & 1.64 \\
\hline Manufacture & & & $-0.32[-0.36]^{* * *}$ \\
\hline Utilities & & & $-0.01[-0.01]$ \\
\hline Construction & & & $-0.24[-0.23]^{* *}$ \\
\hline Retail & & & $-0.21[-0.29]^{*}$ \\
\hline Transp. \& tourism & & & $-0.29[-0.27]^{* *}$ \\
\hline Telecommunications & & & $-0.18[-0.16]^{*}$ \\
\hline Holding activities & & & omitted $^{a}$ \\
\hline Finance & & & $-0.06[-0.06]$ \\
\hline Business services & & & $-0.25[-0.21]^{* *}$ \\
\hline Social \& public serv. & & & $-0.24[-0.23]$ \\
\hline Constant & $8.07 * * *$ & $7.63 * * *$ & $7.96 * * *$ \\
\hline $\mathrm{R}^{2}$ & 0.09 & 0.22 & 0.33 \\
\hline Mean VIF & 1.00 & 1.10 & 2.56 \\
\hline
\end{tabular}

$*, * *, * * *$ denote significance at the $90 \%, 95 \%$ and $99 \%$ level of confidence, respectively

Standardized coefficients between square brackets

${ }^{a}$ denotes results which have been omitted because of multicollinearity 
Table 4

Regression results: Model 2

\begin{tabular}{|c|c|c|c|}
\hline Variables & (2a) & (2b) & (2c) \\
\hline Employees & $-0.01[0.01]$ & $0.15[0.10]$ & 0.13 [0.09] \\
\hline Customers & $-0.11[-0.08]$ & $-0.14[-0.10]$ & $-0.07[-0.05]$ \\
\hline Investors & $0.65[0.52]^{* * *}$ & $0.55[0.44]^{* * *}$ & $0.50[0.41]^{* * *}$ \\
\hline Community & $0.37[0.21]$ & $0.25[0.14]$ & $0.20[0.11]$ \\
\hline Regulators & $-0.26[-0.24]^{*}$ & $-0.30[-0.27]^{* *}$ & $-0.41[-0.38]^{* * *}$ \\
\hline Partners & $0.21[0.13]$ & $0.26[0.17]$ & $0.34[0.22]$ \\
\hline Activists & $0.05[0.05]$ & $0.05[0.05]$ & $0.02[0.02]$ \\
\hline Media & $-0.13[-0.15]$ & $-0.17[-0.20]^{*}$ & $-0.17[-0.21]^{* *}$ \\
\hline Age & & $0.00[-0.10]$ & $0.00[-0.05]$ \\
\hline Size & & $0.05[0.36]^{* * *}$ & $0.05[0.32]^{* *}$ \\
\hline ROA & & $0.29[0.09]$ & $0.45[0.14]^{*}$ \\
\hline Industry: & & & 1.61 \\
\hline Manufacture & & & $-0.35[-0.40]^{* * *}$ \\
\hline Utilities & & & $-0.11[-0.09]$ \\
\hline Construction & & & $-0.20[-0.18]^{*}$ \\
\hline Retail & & & $-0.23[-0.32]^{*}$ \\
\hline Transp. \& tourism & & & $-0.37[-0.35]^{* * *}$ \\
\hline Telecommunications & & & $-0.24[-0.22]^{*}$ \\
\hline Holding activities & & & omitted $^{a}$ \\
\hline Finance & & & $-0.14[-0.16]$ \\
\hline Business services & & & $-0.14[-0.12]$ \\
\hline Social \& public serv. & & & $-0.15[-0.14]$ \\
\hline Constant & $8.09 * * *$ & $7.67^{* * *}$ & $7.96 * * *$ \\
\hline $\mathrm{R}^{2}$ & 0.32 & 0.42 & 0.49 \\
\hline Mean VIF & 1.47 & 1.47 & 2.65 \\
\hline
\end{tabular}

* *,**,*** denote significance at the $90 \%, 95 \%$ and $99 \%$ level of confidence, respectively

Standardized coefficients between square brackets

${ }^{a}$ denotes results which have been omitted because of multicollinearity 